NASA/TM-2003-212555



$\mathrm{SiC}$ Fiber-Reinforced Celsian Composites

Narottam P. Bansal

Glenn Research Center, Cleveland, Ohio 
Since its founding, NASA has been dedicated to the advancement of aeronautics and space science. The NASA Scientific and Technical Information (STI) Program Office plays a key part in helping NASA maintain this important role.

The NASA STI Program Office is operated by Langley Research Center, the Lead Center for NASA's scientific and technical information. The NASA STI Program Office provides access to the NASA STI Database, the largest collection of aeronautical and space science STI in the world. The Program Office is also NASA's institutional mechanism for disseminating the results of its research and development activities. These results are published by NASA in the NASA STI Report Series, which includes the following report types:

- $\quad$ TECHNICAL PUBLICATION. Reports of completed research or a major significant phase of research that present the results of NASA programs and include extensive data or theoretical analysis. Includes compilations of significant scientific and technical data and information deemed to be of continuing reference value. NASA's counterpart of peerreviewed formal professional papers but has less stringent limitations on manuscript length and extent of graphic presentations.

- TECHNICAL MEMORANDUM. Scientific and technical findings that are preliminary or of specialized interest, e.g., quick release reports, working papers, and bibliographies that contain minimal annotation. Does not contain extensive analysis.

- CONTRACTOR REPORT. Scientific and technical findings by NASA-sponsored contractors and grantees.
- CONFERENCE PUBLICATION. Collected papers from scientific and technical conferences, symposia, seminars, or other meetings sponsored or cosponsored by NASA.

- SPECIAL PUBLICATION. Scientific, technical, or historical information from NASA programs, projects, and missions, often concerned with subjects having substantial public interest.

- TECHNICAL TRANSLATION. Englishlanguage translations of foreign scientific and technical material pertinent to NASA's mission.

Specialized services that complement the STI Program Office's diverse offerings include creating custom thesauri, building customized databases, organizing and publishing research results ... even providing videos.

For more information about the NASA STI Program Office, see the following:

- Access the NASA STI Program Home Page at http://www.sti.nasa.gov

- E-mail your question via the Internet to help@sti.nasa.gov

- Fax your question to the NASA Access Help Desk at 301-621-0134

- Telephone the NASA Access Help Desk at 301-621-0390

- Write to:

NASA Access Help Desk

NASA Center for AeroSpace Information 7121 Standard Drive

Hanover, MD 21076 
NASA/TM-2003-212555

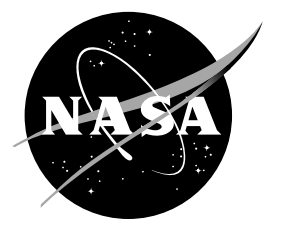

\section{SiC Fiber-Reinforced Celsian Composites}

Narottam P. Bansal

Glenn Research Center, Cleveland, Ohio

National Aeronautics and

Space Administration

Glenn Research Center 


\section{Acknowledgments}

The author would like to thank his collaborators, Dr. Sung Choi, Dr. Jeff Eldridge, Dr. John Gyekenyesi, and Mr. Mark Hyatt (NASA Glenn Research Center), Dr. Özer Ünal (Ames Laboratory), Professor Charles Drummond (OSU), Professor K.P.D. Lagerlof (CWRU), Dr. Rob Dickerson (Los Alamos Laboratory), and Dr. Philippe Colomban

(CNRS, France) who made valuable contributions to the Celsian matrix composites project over the last many years. John Setlock, Ralph Garlick, Ron Phillips, Bob Angus, and Ralph Pawlik provided valuable technical assistance during composite fabrication and characterization.

Trade names or manufacturers' names are used in this report for identification only. This usage does not constitute an official endorsement, either expressed or implied, by the National Aeronautics and Space Administration.

The Propulsion and Power Program at NASA Glenn Research Center sponsored this work.

Available from

NASA Center for Aerospace Information 7121 Standard Drive

Hanover, MD 21076
National Technical Information Service 5285 Port Royal Road Springfield, VA 22100 


\title{
SiC Fiber-Reinforced Celsian Composites
}

\author{
Narottam P. Bansal \\ National Aeronautics and Space Administration \\ Glenn Research Center \\ Cleveland, Ohio 44135 \\ Phone: 216-433-3855; Email: Narottam.P.Bansal@nasa.gov
}

\begin{abstract}
Summary
Celsian is a promising matrix material for fiber-reinforced composites for high temperature structural applications. Processing and fabrication of small diameter multifilament silicon carbide tow reinforced celsian matrix composites are described. Mechanical and microstructural properties of these composites at ambient and elevated temperatures are presented. Effects of high-temperature exposures in air on the mechanical behavior of these composites are also given. The composites show mechanical integrity up to $\sim 1100{ }^{\circ} \mathrm{C}$ but degrade at higher temperatures in oxidizing atmospheres. A model has been proposed for the degradation of these composites in oxidizing atmospheres at high temperatures.
\end{abstract}

\section{Introduction}

Fiber-reinforced ceramic matrix composites are being developed for high-temperature structural applications in aerospace, energy conservation, power generation, nuclear, petrochemical, and other industries. Glasses and glass-ceramics of various compositions (refs. 1 and 2) are being investigated as matrix materials for fiber-reinforced composites. Maximum use temperatures of these matrices in composite form are compared in table 1. Barium aluminosilicate (BAS) glass-ceramic having monoclinic celsian, $\mathrm{BaAl}_{2} \mathrm{Si}_{2} \mathrm{O}_{8}$, as the crystalline phase appears to be the most refractory with a projected maximum use temperature of $\sim 1590{ }^{\circ} \mathrm{C}$ and a melting point of $1760{ }^{\circ} \mathrm{C}$. Celsian shows excellent resistance towards oxidation and reduction, has good thermal shock resistance because of its low thermal expansion coefficient, and does not undergo any phase transformation up to $\sim 1590{ }^{\circ} \mathrm{C}$. It also shows reasonably good resistance against alkali attack. It is chemically compatible with various reinforcement materials such as $\mathrm{SiC}, \mathrm{Si}_{3} \mathrm{~N}_{4}, \mathrm{Al}_{2} \mathrm{O}_{3}$, and mullite. It shows thermally stable microwave dielectric properties which makes it useful for applications in electromagnetic windows and radomes, microelectronic packaging, and high voltage condensers. Also it is highly effective (refs. 3 and 4) as an environmental barrier coating (EBC) for the protection of $\mathrm{SiC}_{\mathrm{f}} / \mathrm{SiC}$ combustor liner in the harsh atmosphere of turbine engines. Therefore, celsian is an attractive matrix material for fiber-reinforced composites for applications as high temperature structural materials in hot sections of gas turbine engines. Celsian composites reinforced with small diameter multifilament tow SiC fibers are described here. Processing and properties of large CVD SiC filament reinforced celsian matrix composites are reported elsewhere (refs. 5 to 11). 
Table 1.-Glass and glass-ceramic matrices of interest for fiber-reinforced composites (refs. 1 and 2)

\begin{tabular}{|c|c|c|c|c|}
\hline $\begin{array}{l}\text { Matrix } \\
\text { type }\end{array}$ & $\begin{array}{c}\text { Major } \\
\text { constituents }\end{array}$ & $\begin{array}{c}\text { Minor } \\
\text { constituents }\end{array}$ & $\begin{array}{l}\text { Major } \\
\text { crystalline } \\
\text { phases }\end{array}$ & $\begin{array}{l}\text { Maximum use temperature } \\
\text { in composite form, }{ }^{\circ} \mathrm{C}\end{array}$ \\
\hline $\begin{array}{l}\text { Glasses }^{\mathrm{a}} \\
7740 \text { Borosilicate } \\
1723 \text { Aluminosilicate } \\
7930 \text { High silica }\end{array}$ & $\begin{array}{c}\mathrm{B}_{2} \mathrm{O}_{3}, \mathrm{SiO}_{2} \\
\mathrm{Al}_{2} \mathrm{O}_{3}, \mathrm{MgO}, \mathrm{CaO}, \mathrm{SiO}_{2} \\
\mathrm{SiO}_{2}\end{array}$ & $\begin{array}{c}\mathrm{Na}_{2} \mathrm{O}, \mathrm{Al}_{2} \mathrm{O}_{3} \\
\mathrm{~B}_{2} \mathrm{O}_{3}, \mathrm{BaO} \\
\mathrm{B}_{2} \mathrm{O}_{3} \\
\end{array}$ & $\begin{array}{l}-- \\
-- \\
--\end{array}$ & $\begin{array}{c}600 \\
700 \\
1150 \\
\end{array}$ \\
\hline $\begin{array}{l}\text { Glass-ceramics } \\
\text { LAS-I } \\
\text { LAS-II } \\
\text { LAS-III } \\
\text { MAS } \\
\text { BMAS } \\
\text { Ternary mullite } \\
\text { Celsian }\end{array}$ & $\begin{array}{c}\mathrm{Li}_{2} \mathrm{O}, \mathrm{Al}_{2} \mathrm{O}_{3}, \mathrm{MgO}, \mathrm{SiO}_{2}, \\
\mathrm{Li}_{2} \mathrm{O}, \mathrm{Al}_{2} \mathrm{O}_{3}, \mathrm{MgO}, \mathrm{SiO}_{2}, \mathrm{Nb}_{2} \mathrm{O}_{5} \\
\mathrm{Li}_{2} \mathrm{O}, \mathrm{Al}_{2} \mathrm{O}_{3}, \mathrm{MgO}, \mathrm{SiO}_{2}, \mathrm{Nb}_{2} \mathrm{O}_{5} \\
\mathrm{MgO}, \mathrm{Al}_{2} \mathrm{O}_{3}, \mathrm{SiO}_{2} \\
\mathrm{BaO}, \mathrm{MgO}, \mathrm{Al}_{2} \mathrm{O}_{3}, \mathrm{SiO}_{2} \\
\mathrm{BaO}, \mathrm{Al}_{2} \mathrm{O}_{3}, \mathrm{SiO}_{2} \\
\mathrm{BaO}, \mathrm{Al}_{2} \mathrm{O}_{3}, \mathrm{SiO}_{2}\end{array}$ & $\begin{array}{c}\mathrm{ZnO}, \mathrm{ZrO}_{2}, \mathrm{BaO} \\
\mathrm{ZnO}, \mathrm{ZrO}_{2}, \mathrm{BaO} \\
\mathrm{ZrO}_{2} \\
\mathrm{BaO} \\
-- \\
-- \\
--\end{array}$ & $\begin{array}{c}\beta \text {-spodumene } \\
\beta \text {-spodumene } \\
\beta \text {-spodumene } \\
\text { Cordierite } \\
\text { Barium osumilite } \\
\text { Mullite } \\
\text { Celsian }\end{array}$ & $\begin{array}{c}1000 \\
1100 \\
1200 \\
1200 \\
1250 \\
\sim 1500 \\
\sim 1600\end{array}$ \\
\hline
\end{tabular}

${ }^{\mathrm{a}} 7740,1723$, and 7930 are Corning Glass Works designations

\section{Polymorphs and Crystal Structure of Celsian}

Celsian (monoclinic space group I2/c) can exist in three different forms: monoclinic, hexagonal and orthorhombic. Hexacelsian (space group $\mathrm{P} 6 / \mathrm{mmm}$ ) is the high temperature polymorph and is thermodynamically stable above $1590{ }^{\circ} \mathrm{C}$, but once formed can metastably exist in the entire temperature range down to room temperature (fig. 1) (refs. 12 and 13). The kinetics of transformation of hexacelsian into monoclinic celsian is very sluggish (ref. 14). Hexacelsian shows a large thermal expansion coefficient of $\sim 8.0 \times 10^{-6} /{ }^{\circ} \mathrm{C}$ and undergoes a rapid, reversible structural transformation into the orthorhombic form at $\sim 300{ }^{\circ} \mathrm{C}$, accompanied by a large volume change of $\sim 3$ percent. In the presence of hexacelsian, thermal cycling of the composite would result in microcracking of the BAS matrix. Obviously, if BAS is to be successfully used as a matrix material for fiber reinforced composites, the processing conditions need to be designed to completely eliminate the undesirable hexacelsian phase.

The crystal structure of hexacelsian (figs. 2 and 3(a)) (ref. 15) contains infinite two-dimensional hexagonal sheets, consisting of two layers of silica tetrahedral sharing all four vertices with substitution of $\mathrm{Al}$ for $\mathrm{Si}$ and charge compensation by $\mathrm{Ba}$ between the sheets. It has been suggested (ref. 16) that the transformation at $300{ }^{\circ} \mathrm{C}$ between orthorhombic and hexagonal forms of hexacelsian involves rotation of these sheets with respect to each other. However, according to Takeuchi (ref. 16), no significant differences are observed between the powder XRD patterns of the orthorhombic and hexagonal forms of hexacelsian except peak shifts owing to lattice expansion, indicating similar fundamental frameworks of both structures.

The celsian structure (fig. 3(b)) (ref. 17) is similar to the feldspar structure in which all four vertices of the silica tetrahedral are shared, forming a three-dimensional network. As in hexacelsian, Al substitutes for Si with charge compensation by $\mathrm{Ba}$ in the larger interstices of the structure. Gay (ref. 18) and Newnham and Megaw (ref. 17) considered the formation of a superlattice in celsian associated with ordering of the Al-Si atoms.

In celsian crystal structure (ref. 19) the $\mathrm{Al}$ and $\mathrm{Si}$ atoms are statistically distributed over tetrahedral sites, so that each $\mathrm{Al}$ tetrahedron is surrounded by four predominantly Si tetrahedral and vice versa. The feature of the hexacelsian structure, however, is the presence of $(\mathrm{Al}, \mathrm{Si}) \mathrm{O}_{4}$ tetrahedra which share three corners so that a hexagonal sheet results with the remaining apices pointing in the same direction. Two of these sheets share their apical oxygens, forming a double tetrahedral sheet (fig. 3(a)). Ba atoms occupy positions between the double sheets with twelve equidistant oxygen neighbors. In celsian, Ba ion has an irregular configuration, so that it has ten oxygen neighbors at several Ba-O distances. Consequently, to transform hexacelsian to celsian would require creation of a three-dimensional network from the two-dimensional sheet structure of hexacelsian as well as rearrangement of the Ba sites. This would entail breaking and reforming of Al-O and $\mathrm{Si}-\mathrm{O}$ bonds. Some of the physical, mechanical and thermal properties of celsian are given in table 2 (refs. 20 to 22). 


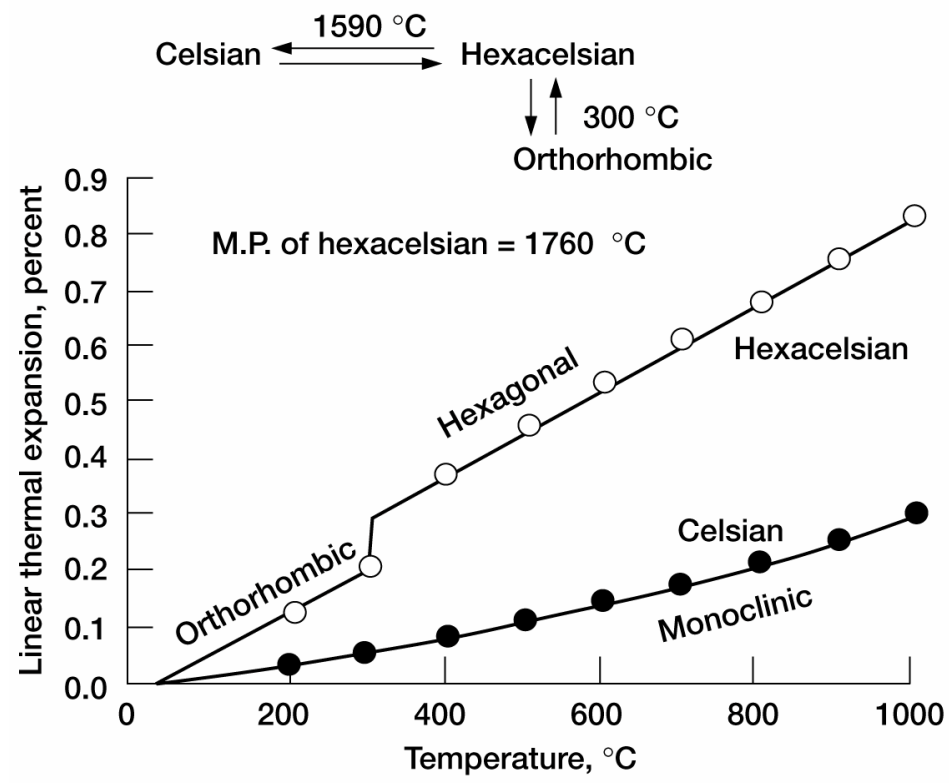

Figure 1.-Linear thermal expansion of hexacelsian and monoclinic celsian BAS.

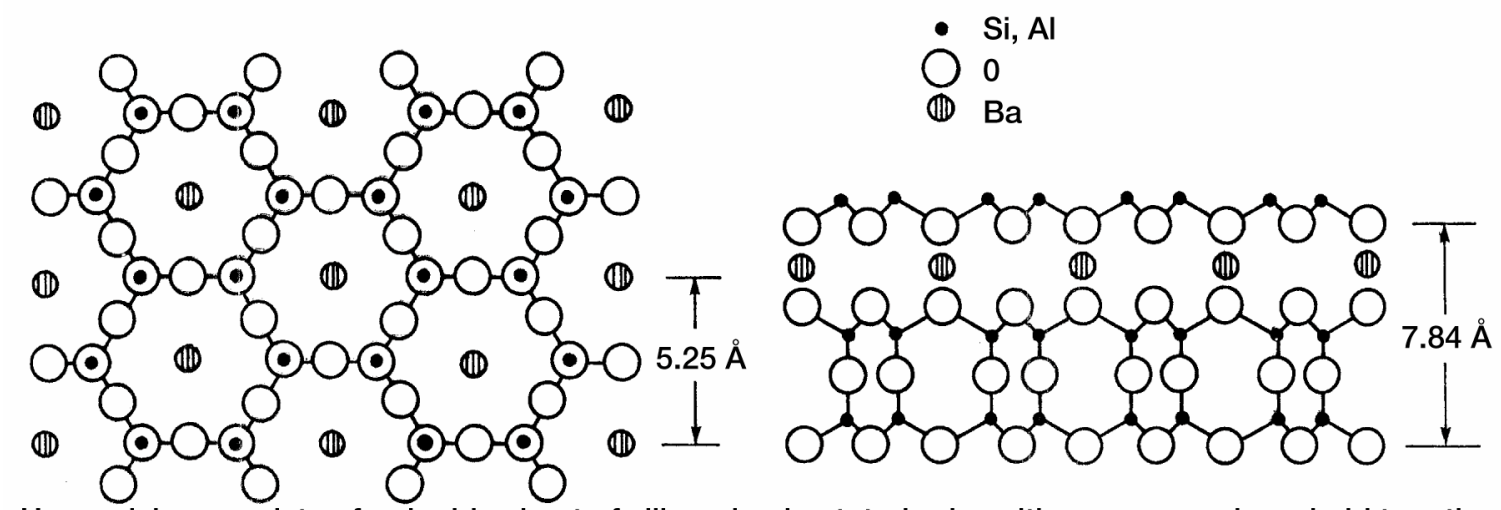

Hexacelsian consists of a double sheet of silica-alumina tetrahedra with common apices, held together by barium ions in 12-fold coordination.

Figure 2.-Structure of hexagonal $\mathrm{BaAl}_{2} \mathrm{Si}_{2} \mathrm{O}_{8}$. 


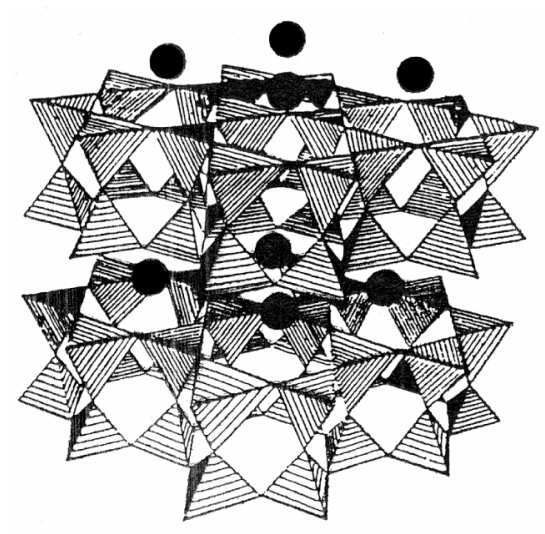

(a)

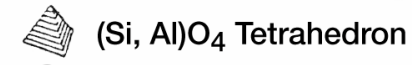

$\mathrm{Ba}$

Figure 3.-Crystal structures of (a) hexagonal and (b) monoclinic celsian $\mathrm{BaAl}_{2} \mathrm{Si}_{2} \mathrm{O}_{8}$.

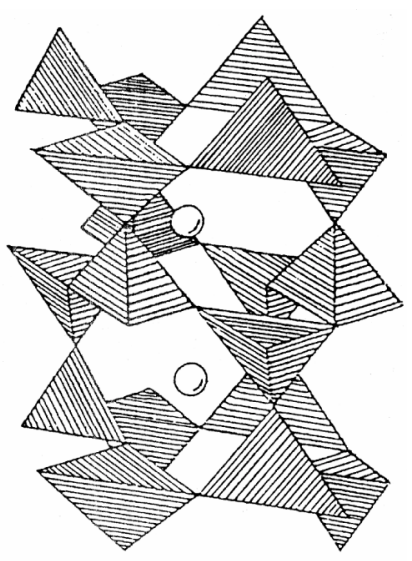

(Si, $\mathrm{Al}) \mathrm{O}_{4}$ Tetrahedron

$\mathrm{Ba}$ (b)

Table 2.-Properties of celsian

\begin{tabular}{|c|c|c|}
\hline Property & Temperature & Value \\
\hline Melting point, ${ }^{\circ} \mathrm{C}$ & -- & 1760 \\
\hline Density, $\mathrm{g} / \mathrm{cm}^{-3}$ & RT & $\begin{array}{c}3.39 \text { (monoclinic celsian) } \\
3.26 \text { (hexacelsian) }\end{array}$ \\
\hline $\mathrm{CTE},{ }^{\circ} \mathrm{C}^{-1}$ & $\begin{array}{l}20 \text { to } 1000^{\circ} \mathrm{C} \\
300 \text { to } 1000^{\circ} \mathrm{C}\end{array}$ & $\begin{array}{c}2.29 \times 10^{-6}(\text { monoclinic celsian }) \\
8 \times 10^{-6}(\text { hexacelsian })\end{array}$ \\
\hline Flexure modulus, GPa & $\begin{array}{c}\mathrm{RT} \\
538^{\circ} \mathrm{C} \\
815^{\circ} \mathrm{C} \\
1093^{\circ} \mathrm{C}\end{array}$ & $\begin{array}{c}100 \pm 7 \\
102 \pm 14 \\
94 \pm 8 \\
87 \pm 6\end{array}$ \\
\hline Poisson's ratio & RT & 0.32 \\
\hline Flexure (4-point) strength, $\mathrm{MPa}$ & $\begin{array}{c}\mathrm{RT} \\
500^{\circ} \mathrm{C} \\
750{ }^{\circ} \mathrm{C} \\
1000^{\circ} \mathrm{C} \\
1200^{\circ} \mathrm{C} \\
1350{ }^{\circ} \mathrm{C} \\
\end{array}$ & $\begin{array}{c}115 \pm 15 \\
120 \pm 5 \\
100 \pm 10 \\
60 \pm 5 \\
25 \pm 5 \\
25 \pm 5\end{array}$ \\
\hline Fracture toughness, $\mathrm{MPa} / \mathrm{m}^{1 / 2}$ & RT & 1.56 \\
\hline Thermal diffusivity, $\mathrm{cm}^{2} \mathrm{~s}^{-1}$ & RT & 0.0114 \\
\hline Heat capacity, $\mathrm{Jg}^{-1} \mathrm{~K}^{-1}$ & $\begin{array}{c}\mathrm{RT} \\
260^{\circ} \mathrm{C} \\
538^{\circ} \mathrm{C} \\
815^{\circ} \mathrm{C} \\
1093^{\circ} \mathrm{C} \\
1372^{\circ} \mathrm{C}\end{array}$ & $\begin{array}{l}0.84 \\
0.79 \\
0.88 \\
0.88 \\
0.94 \\
1.02\end{array}$ \\
\hline Thermal conductivity, $\mathrm{Wm}^{-1} \mathrm{~K}^{-1}$ & $\begin{array}{c}\mathrm{RT} \\
500^{\circ} \mathrm{C} \\
1000^{\circ} \mathrm{C} \\
1400^{\circ} \mathrm{C}\end{array}$ & $\begin{array}{c}3.25 \\
3.1 \\
3.0 \\
2.9\end{array}$ \\
\hline
\end{tabular}




\section{Formation of Monoclinic Celsian}

On heat treatment, both hexacelsian and monoclinic celsian phases crystallize in BAS glass (refs. 23 to 25). Also, hot pressing of barium aluminosilicate (BAS) glass or its composites reinforced with large diameter silicon carbide SCS-6 monofilaments or small diameter multifilament Nicalon or Hi-Nicalon fibers resulted in the crystallization of both hexacelsian and monoclinic celsian phases (ref. 12). On doping BAS with $5 \mathrm{wt} . \%$ monoclinic celsian seeds or $10 \mathrm{wt} . \%$ strontium aluminosilicate (SAS), only the celsian phase was formed in hot pressed monolithic specimens. However, in fiber-reinforced composites hot pressed under similar conditions, a small concentration of hexacelsian was still present as hexacelsian nucleates preferentially on the surface and the presence of fibers provides a large surface area. When the additive concentration increased to $10 \mathrm{wt} . \%$ celsian seeds or $20 \mathrm{wt} . \%$ SAS, celsian was the only phase detected from x-ray diffraction, with complete elimination of hexacelsian, in the hot pressed composites reinforced with SiC fibers. Hence BAS with 20 to 25 percent of SAS was used as the matrix for fiber-reinforced composites.

\section{CMC Processing}

Ceramic grade Nicalon or Hi-Nicalon fiber tows were used as the reinforcement. Fibers having a dual surface layer of $\mathrm{BN}$ overcoated with $\mathrm{SiC}$ were used. $\mathrm{BN}$ acts as a weak, crack deflecting, compliant layer, while the $\mathrm{SiC}$ overcoat acts as a barrier to diffusion of boron from $\mathrm{BN}$ into the oxide matrix and also prevents diffusion of matrix elements into the fiber.

The matrix of $0.75 \mathrm{BaO}-0.25 \mathrm{SrO}-\mathrm{Al}_{2} \mathrm{O}_{3}-2 \mathrm{SiO}_{2}$ (BSAS) composition was synthesized (ref. 20) by a solidstate reaction method from $\mathrm{BaCO}_{3}, \mathrm{SrCO}_{3}, \mathrm{Al}_{2} \mathrm{O}_{3}$, and $\mathrm{SiO}_{2}$ powders. The mixed powder was calcined at $\sim 900$ to $910{ }^{\circ} \mathrm{C}$ for decomposition of the carbonates. The resulting powder consisted of mainly $\mathrm{SiO}_{2}$ ( $\alpha$-quartz) and $\mathrm{BaAl}_{2} \mathrm{O}_{4}$ phases with small amounts of $\mathrm{Ba}_{2} \mathrm{SiO}_{4}, \alpha-\mathrm{Al}_{2} \mathrm{O}_{3}$, and $\mathrm{Ba}_{2} \mathrm{Sr}_{2} \mathrm{Al}_{2} \mathrm{O}_{7}$ also present. This powder was made into slurry by dispersing it in methyl ethyl ketone along with organic additives as binder, surfactant, deflocculant and plasticizer followed by ball milling. BSAS glass powder, custom melted by an outside vendor, was also used as precursor to celsian matrix in the fabrication of some composite panels.

Schematic of the set-up used for fabrication of FRC by matrix slurry infiltration is shown in figure 4 (ref. 26). The fiber tows are impregnated with the matrix precursor by passing it through the slurry. Excess slurry is squeezed out of the fiber tow before winding it on a rotating drum. After drying, the prepreg tape is cut to size, stacked up in desired orientation, and warm pressed resulting in a "green" composite. The fugitive
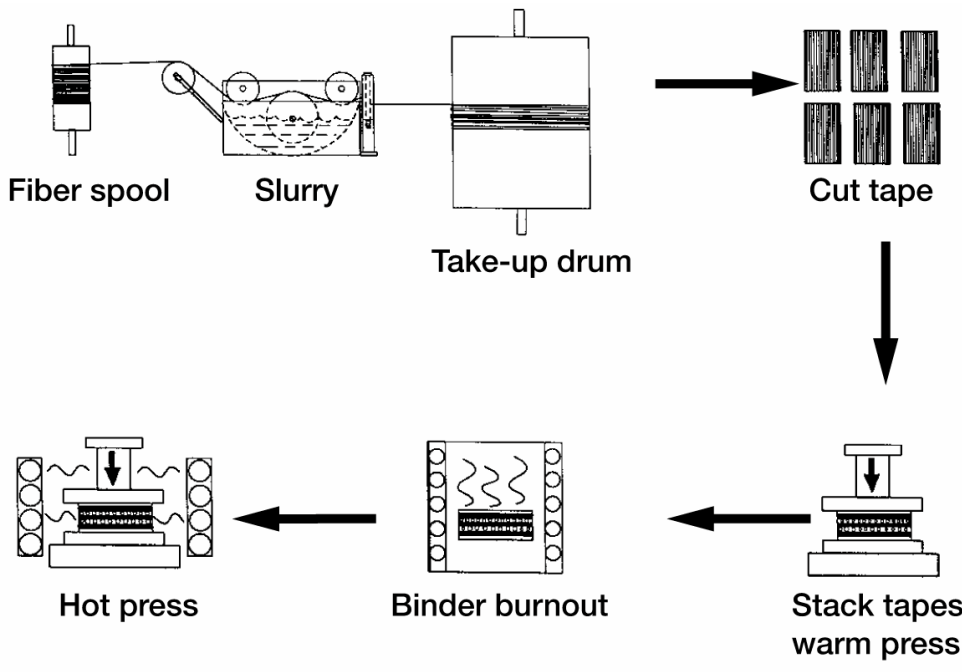

Figure 4.-Schematic of the set up used for fabrication of small diameter, multifilament fiber tow reinforced ceramic composites. organics are slowly burned out of the sample in air followed by hot pressing in a graphite die resulting in almost fully dense composite.

X-ray diffraction (fig. 5) from the surface of a hot pressed composite panel (ref. 27) showed only the desired monoclinic celsian. This indicates that the mixed oxide precursor is converted in situ into the monoclinic celsian phase during hot pressing of the FRC. The undesired hexacelsian phase was not detected from XRD. However, a small amount of hexacelsian was detected by Raman micro-spectroscopy (ref. 28). The hot pressed composite panel was surface polished and sliced into test bars for mechanical testing. 


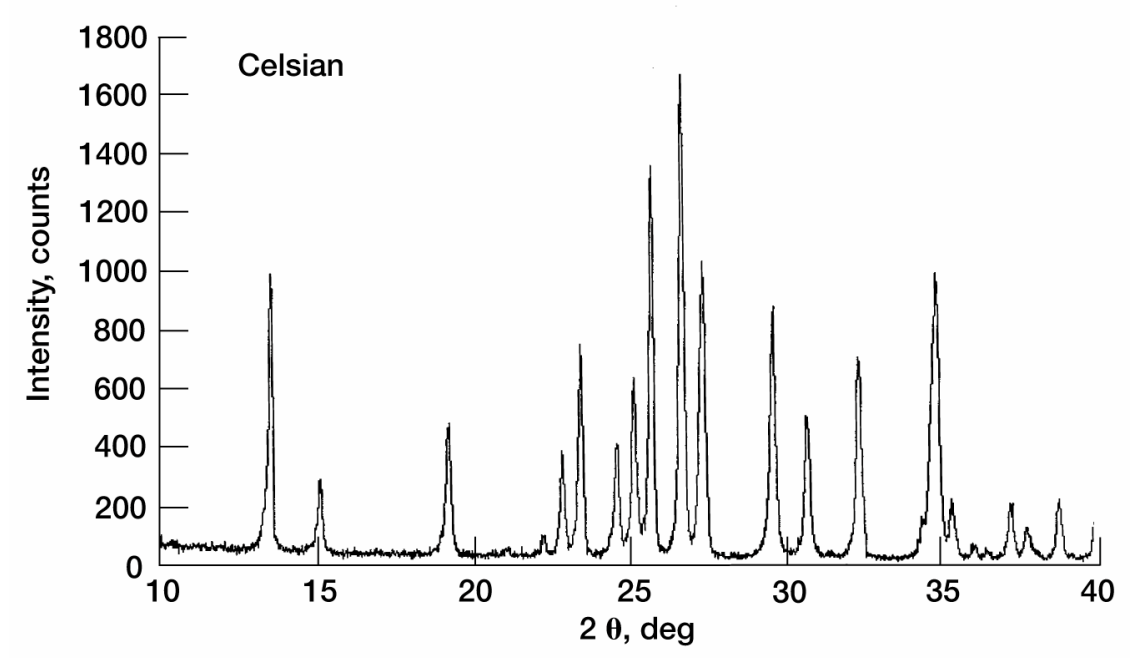

Figure 5.-X-ray diffraction from surface of a hot pressed Hi-Nicalon/BSAS composite.

Table 3.- Mechanical properties* of $0 / 90^{\circ}$ Nicalon/BN/SiC/BSAS composites at various temperatures in air, $V_{f}=0.38$ to 0.40

\begin{tabular}{|l|c|c|c|c|}
\hline $\begin{array}{c}\text { Temperature, } \\
{ }^{\circ} \mathrm{C}\end{array}$ & $\begin{array}{c}\text { Yield stress, } \sigma_{y} \\
\mathrm{MPa}\end{array}$ & $\begin{array}{c}\text { Modulus, } E_{c} \\
\mathrm{GPa}\end{array}$ & $\begin{array}{c}\text { Ultimate strength, } \sigma_{u} \\
\mathrm{MPa}\end{array}$ & $\begin{array}{c}\text { Failure strain, } \\
\text { percent }\end{array}$ \\
\hline 25 & $75 \pm 1$ & $92 \pm 1$ & $289 \pm 9$ & $0.43 \pm 0.01$ \\
\hline 550 & $85 \pm 1$ & $88 \pm 5$ & $282 \pm 21$ & $0.45 \pm 0.04$ \\
\hline 1100 & $60 \pm 15$ & $80 \pm 6$ & $208 \pm 1$ & $0.34 \pm 0.01$ \\
\hline 1200 & $44 \pm 5$ & $63 \pm 3$ & $187 \pm 20$ & $0.39 \pm 0.03$ \\
\hline 1300 & $32 \pm 8$ & $54 \pm 3$ & $180 \pm 45$ & $0.55 \pm 0.10$ \\
\hline
\end{tabular}

*Measured in 4-point flexure

\section{Nicalon/Celsian Composites}

\subsection{Flexure Strength}

Flexure strength was measured in four-point bending using an upper span of $0.75 \mathrm{in}$. and a lower span of 2.5 in. Flexural properties (refs. 29 to 31 ) of $0 / 90^{\circ}$ cross-ply Nicalon/BN/SiC/BSAS composites, containing 38 to 40 volume percent of fibers, at various temperatures in air are shown in table 3 .

\subsection{Effects of High-Temperature Annealing in Air}

Thermal-oxidative stability of Nicalon/BN/SiC/BSAS composites has also been investigated (refs. 29 to 31 ). The $0 / 90^{\circ}$ cross-ply composites, containing $\sim 40$ volume percent of fibers were heat treated in air for 100 to $500 \mathrm{hr}$. at various temperatures between $\sim 550{ }^{\circ} \mathrm{C}$ to $\sim 1300{ }^{\circ} \mathrm{C}$. Glass formation was observed on the surface of specimens annealed at or above $1100{ }^{\circ} \mathrm{C}$. The specimens exposed at $\sim 1200{ }^{\circ} \mathrm{C}$ and $\sim 1300{ }^{\circ} \mathrm{C}$ were so severely covered with glass, along with the presence of some gas bubbles, that these could not be further tested. The residual flexural strengths of the composites after air-annealing are shown 


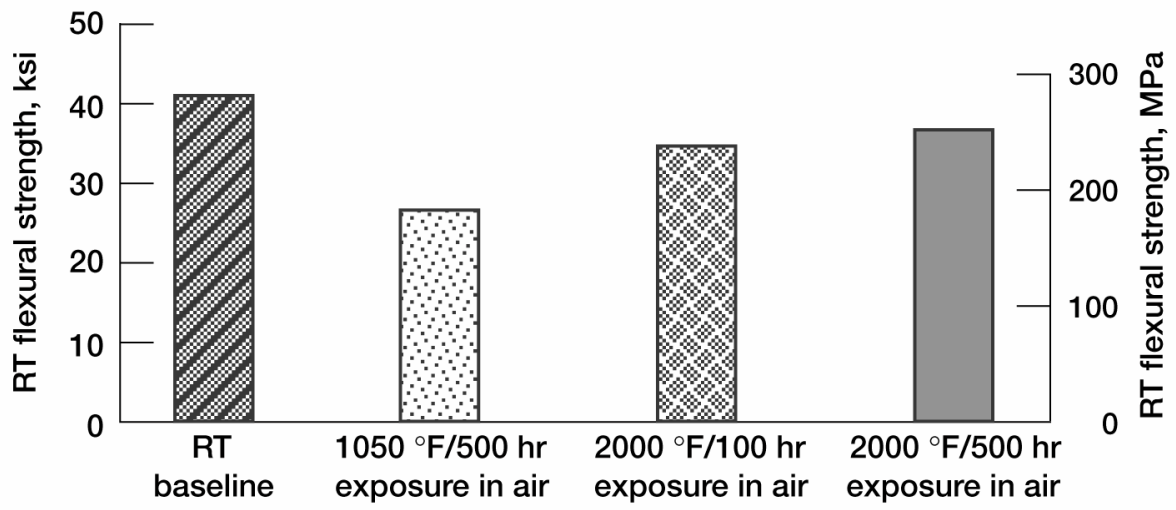

Figure 6.-Effect of air-annealing at various temperatures on room temperature flexural strength of $(0 / 90)$ Nicalon/BSAS composites; $V_{f}=0.4$.

in figure 6 . The sample annealed at $\sim 550{ }^{\circ} \mathrm{C}$ showed 40 percent drop in room temperature strength. This could be due to oxidation of the carbon layer (formed in situ during composite processing) at the fibermatrix interface where the temperature is too low for any residual glassy phase to flow and provide oxidation resistance. However, the specimen exposed at $\sim 1100{ }^{\circ} \mathrm{C}$ retained 90 percent of the baseline strength. At this temperature, the residual glassy phase is less viscous, as seen by gas bubble formation, and may have resulted in the protection of the carbon interface layer from oxidation.

\subsection{Tensile Strength}

Tensile testing was carried out in air at a displacement rate of $0.02 \mathrm{in} . /$ minute. Tensile properties of $0 / 90^{\circ}$ cross-ply Nicalon/BN/SiC/BSAS composites, containing 38 to 40 volume percent of fibers, at various temperatures are shown (refs. 29 to 31 ) in table 4 . Above $\sim 1100{ }^{\circ} \mathrm{C}$, ultimate strength and the proportional limit fall off fairly rapidly, while modulus decreased by $\sim 40$ percent from ambient temperature to $\sim 1300{ }^{\circ} \mathrm{C}$. Nicalon fiber is known to degrade at $\sim 1200{ }^{\circ} \mathrm{C}$ and degradation rate increases with increase in temperature. Presence of residual glassy phase in the matrix would account for the observed decrease in modulus and increase in failure strain at elevated test temperatures.

Effect of test rate on ultimate tensile strength for $0 / 90^{\circ}$ Nicalon/BSAS composite at $1100{ }^{\circ} \mathrm{C}$ in air has also been investigated (ref. 32). Results in figure 7 exhibit a significant dependency of ultimate strength on test rate. The ultimate strength decreased with decreasing test rate, similar to the behavior observed in many advanced monolithic ceramics (or brittle materials including glass and glass ceramics) at ambient or elevated temperature. The strength degradation with decreasing stress rate in brittle materials is known to occur by slow crack growth (delayed failure or fatigue) of an initial crack, and is expressed as:

$$
\log \sigma_{f}=\frac{1}{n+1} \log \dot{\sigma}+\log D
$$

where $n$ and $D$ are slow crack growth $(\mathrm{SCG})$ parameters, and $\sigma_{f}(\mathrm{MPa})$ and $\dot{\sigma}(\mathrm{MPa} / \mathrm{s})$ are strength and stress rate, respectively. These results suggest that care must be exercised when characterizing elevatedtemperature ultimate strength of composite materials. This is due to that fact that high-temperature ultimate strength has a relative meaning if a material exhibits rate dependency: the strength simply depends on which test rate one chooses. Therefore, at least two test rates (high and low) are recommended to better characterize the high-temperature ultimate strength behavior of a composite material. 
Table 4.-Tensile properties of $0 / 90^{\circ}$ Nicalon/BN/SiC/BSAS composites at various temperatures in air, $V_{f}=0.38$ to 0.40

\begin{tabular}{|l|c|c|c|c|}
\hline $\begin{array}{c}\text { Temperature, } \\
{ }^{\circ} \mathrm{C}\end{array}$ & $\begin{array}{c}\text { Yield stress, } \sigma_{y} \\
\mathrm{MPa}\end{array}$ & $\begin{array}{c}\text { Modulus, } E_{c} \\
\mathrm{GPa}\end{array}$ & $\begin{array}{c}\text { Ultimate strength, } \sigma_{u} \\
\mathrm{MPa}\end{array}$ & $\begin{array}{c}\text { Failure strain, } \\
\text { percent }\end{array}$ \\
\hline 25 & $75 \pm 1$ & $97 \pm 12$ & $178 \pm 28$ & $0.43 \pm 0.09$ \\
\hline 550 & $63 \pm 1$ & 87 & 196 & 0.64 \\
\hline 1100 & $63 \pm 6$ & $71 \pm 9$ & $162 \pm 16$ & $0.41 \pm 0.06$ \\
\hline 1200 & $32 \pm 9$ & $63 \pm 3$ & $112 \pm 12$ & $0.50 \pm 0.08$ \\
\hline 1300 & $29 \pm 2$ & $53 \pm 3$ & $153 \pm 3$ & $0.63 \pm 0.06$ \\
\hline
\end{tabular}

Table 5.- Interlaminar shear properties of $0 / 90^{\circ}$

Nicalon/BN/SiC/BSAS composites at

various temperatures in air, $V_{f}=0.38$ to 0.40

\begin{tabular}{|l|c|c|}
\hline $\begin{array}{c}\text { Temperature, } \\
{ }^{\circ} \mathrm{C}\end{array}$ & $\begin{array}{c}\text { Interlaminar shear stress, } \\
\mathrm{MPa}\end{array}$ & $\begin{array}{c}\text { Failure } \\
\text { mode }\end{array}$ \\
\hline 25 & $17 \pm 2$ & Shear \\
\hline 1100 & $10 \pm 3$ & Shear \\
\hline 1200 & $7 \pm 1$ & Shear \\
\hline 1300 & $6 \pm 1$ & Shear \\
\hline
\end{tabular}

*Average of three samples

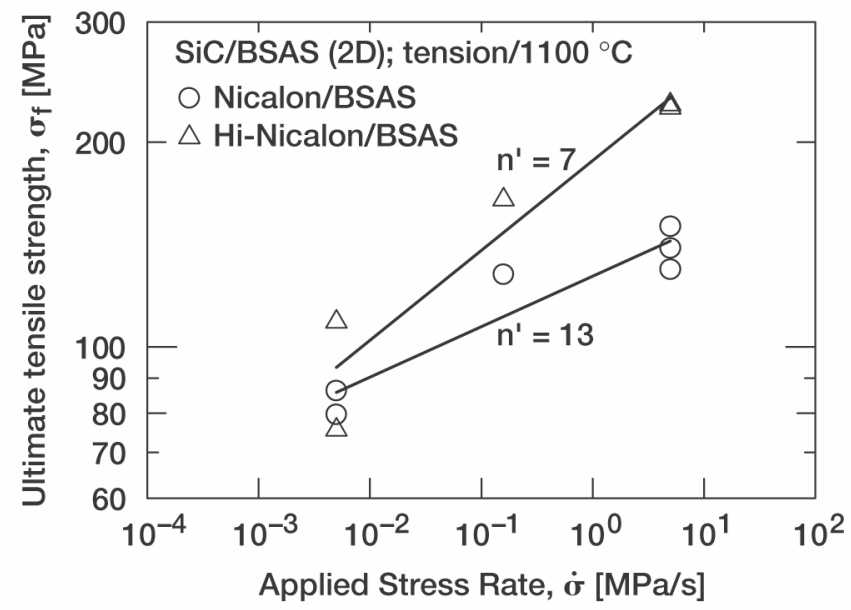

Figure 7.-Results of ultimate tensile strength as a function of applied stress rate determined for Nicalon/BSAS and $\mathrm{Hi}$-Nicalon/BSAS composites at $1100^{\circ} \mathrm{C}$ in air. The solid lines represent the best-fit regression based on eq. (1).

\subsection{Shear Strength}

Interlaminar shear testing was carried out using the short beam shear technique in 3-point bending at a displacement rate of $0.02 \mathrm{in}$./minute from room temperature to $\sim 1300{ }^{\circ} \mathrm{C}$. Results of the interlaminar shear strength (ref. 31) for the $0 / 90^{\circ}$ cross-ply Nicalon/BN/SiC/BSAS composites, containing 38 to 40 volume percent of fibers are given in table 5. The failure mode for all the test specimens was shear. 


\subsection{Tensile Stress-Rupture Strength}

To determine if the composite would provide stress oxidative stability after the matrix is microcracked, stepped stress-rupture tests were carried out. The $0 / 90^{\circ}$ cross-ply Nicalon/BN/SiC/BSAS composites, containing 40 volume percent of fibers, were tested in standard dead weight creep machines at 1100 and $1200{ }^{\circ} \mathrm{C}$ in air. No testing was done at $1300^{\circ} \mathrm{C}$ because of the presence of residual glass in the matrix. Tests were started at stress level near the proportional limit. Approximately every 50 hours, the stress was increased by $2 \mathrm{ksi}(\sim 14 \mathrm{MPa})$ until the sample failed. The results (ref. 31) are shown in figure 8. The composite survived to a stress level of $\sim 60$ percent of its ultimate tensile strength. Examination of the fracture surface of the specimen tested at $\sim 1100{ }^{\circ} \mathrm{C} / 10 \mathrm{ksi}(\sim 70 \mathrm{MPa})$ for $8 \mathrm{hr}$. revealed some embrittlement.

Results of constant stress (stress-rupture) testing for $0 / 90^{\circ}$ Nicalon/BSAS (for two different batches ' $\mathrm{A}$ ' and 'B') at $1100{ }^{\circ} \mathrm{C}$ in air are presented (ref. 32) in figure 9, where time to failure is plotted against applied stress in log-log scales. A decrease in time to failure with increasing applied stress, which represents a susceptibility to damage accumulation or delayed failure, is evident for the composite. The mode of fracture in constant stress testing was similar to that in constant stress-rate testing showing some fiber pullout with jagged matrix cracking through the specimen-thickness direction.

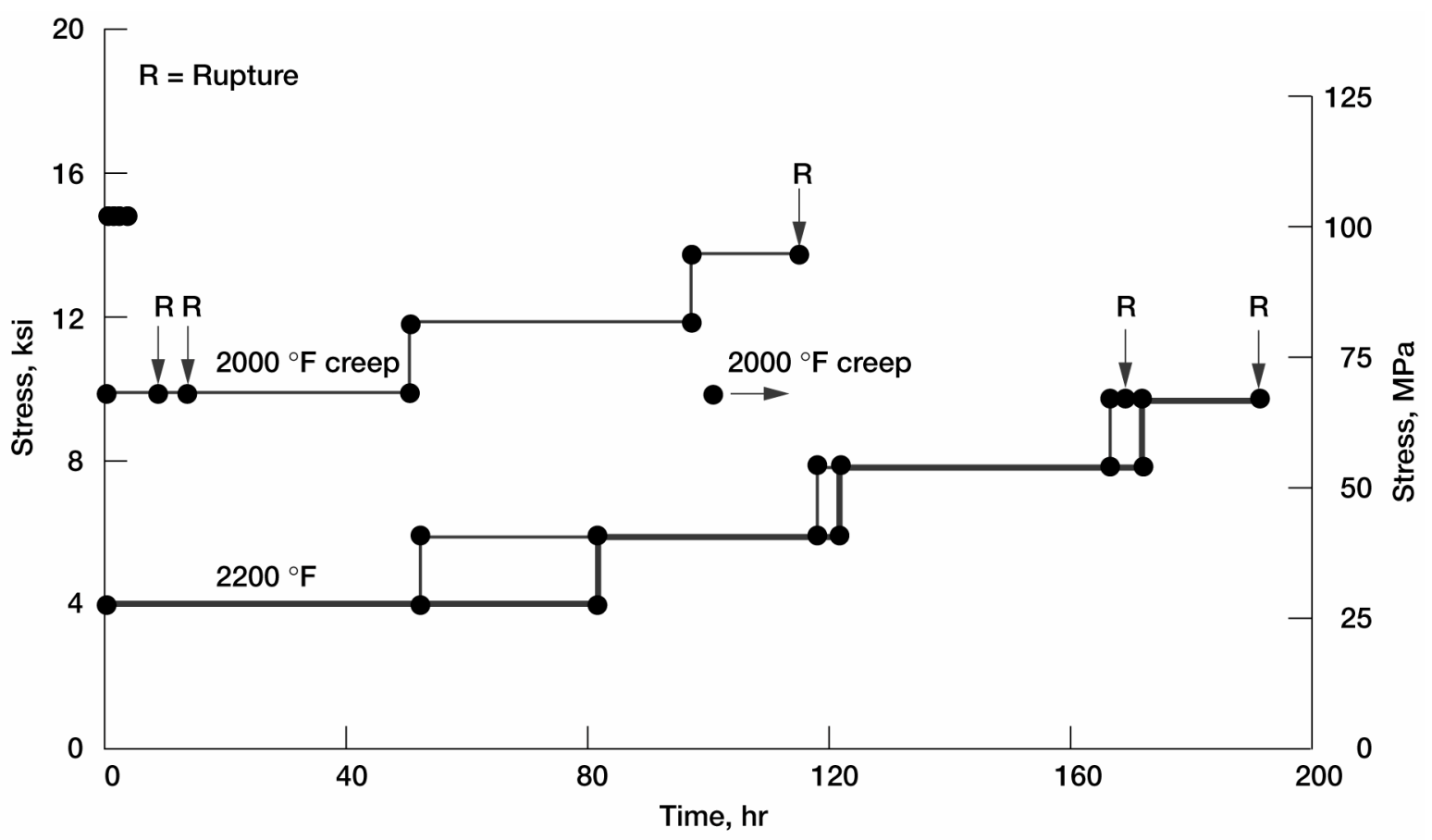

Figure 8.-Tensile stress rupture testing in air of (0/90) Nicalon/BSAS composites; $V_{f}=0.4$ 

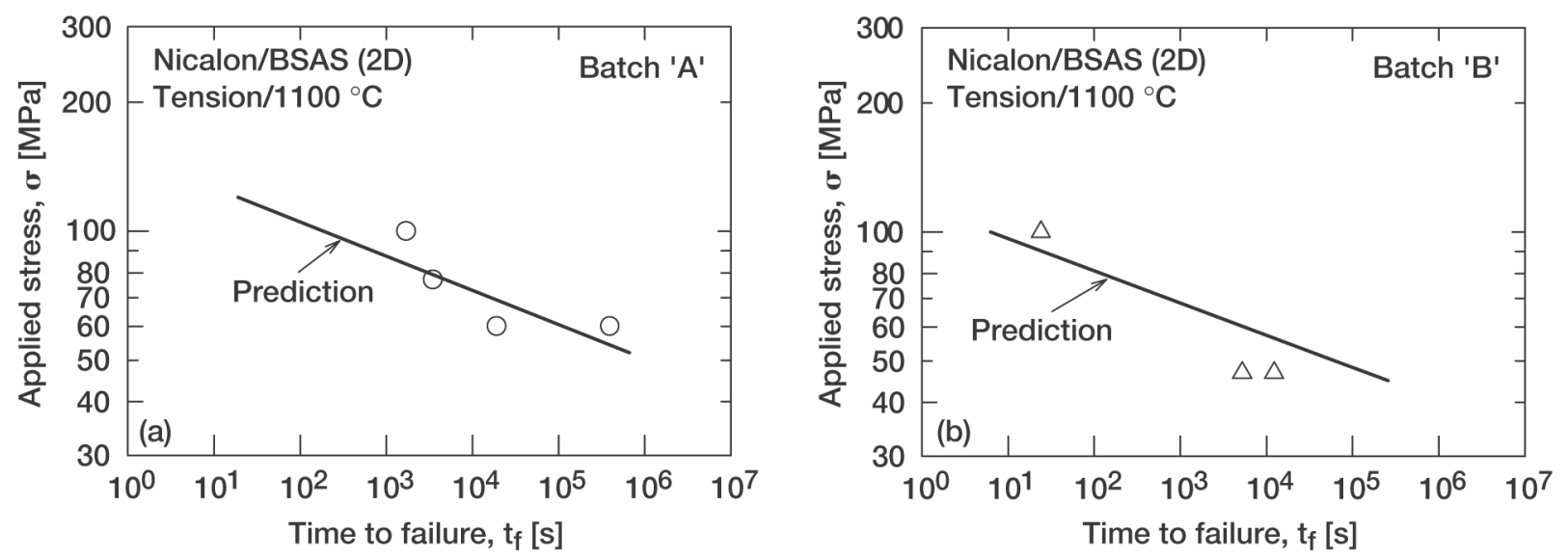

Figure 9.-Results of constant stress ("static fatigue" or "stress rupture") testing for Nicalon/BSAS composite: (a) Batch ' $A$ ' and (b) Batch ' $B$ ' tested at $1100^{\circ} \mathrm{C}$ in air. The solid lines represent the predictions based on the results of constant stress-rate testing (Fig. 7 ).

\section{Hi-Nicalon/Celsian Composites}

SEM micrographs taken from the polished cross-sections of the uncoated and BN/SiC coated Hi-Nicalon fiber-reinforced BSAS composites are shown in figure 10. A large variation in fiber diameter within a tow can be seen although the manufacturer reports an average diameter of $14 \mu \mathrm{m}$. Uniform fiber distribution, good matrix infiltration within the fiber tow, and high composite density is evident. Occasional pores and second matrix phase, appearing as the bright phase, can also be seen. The amount of this second phase must be small, as it was not detected by XRD. This phase has been tentatively identified (ref. 33) as "hyalophane" $\left[(\mathrm{Ba}, \mathrm{Sr}) \mathrm{AlSi}_{3} \mathrm{O}_{8}\right]$ which is richer in $\mathrm{Si}$ and deficient in $\mathrm{Al}$ than celsian. The $\mathrm{BN}$ coating which is the dark layer is adherent to the fiber, but the $\mathrm{SiC}$ coating tends to debond at the $\mathrm{BN} / \mathrm{SiC}$ interface probably during composite processing.

TEM micrograph from the Hi-Nicalon/BN/SiC/BSAS composite (ref. 26) is shown in figure 11(a). Four distinct layers are seen in the $\mathrm{BN}$ coating. The $\mathrm{SiC}$ coating was often found to be missing from the $\mathrm{BN} / \mathrm{matrix}$ interface but was intact in this particular case. Another TEM micrograph (ref. 26) is shown in figure 11(b). The fiber/BN interface and the innermost layer of $\mathrm{BN}$ are unchanged. $\mathrm{BN}$ has coarsened from outside inwards during composite processing. From EDS, no obvious chemical changes were observed in the BN coating. SiC layer was not affected.

\subsection{Flexure Strength}

Typical stress-strain curves, recorded in 3-point flexure, for the uncoated and $\mathrm{BN} / \mathrm{SiC}$ coated fiberreinforced composites (refs. 33 to 34) are shown in figure 12. Also shown for comparison is the stress-strain curve for a hot pressed BSAS monolith. The monolith shows bend strength of $130 \mathrm{MPa}$, modulus of $98 \mathrm{GPa}$ and fails in brittle mode, as expected. The uncoated fiber-reinforced CMC shows a monolithic-like failure with strength of $\sim 200 \mathrm{MPa}$ and failure strain of $\sim 0.1$ percent. This shows that reinforcement of BSAS matrix with uncoated Hi-Nicalon fibers does not yield a strong or tough material. This may indicate a strong bond between the uncoated fibers and the matrix. However, fiber push-in and push-out tests (refs. 33 and 35) indicated a weak fiber-matrix interface in these CMCs. Low strength of these CMCs was found to be due to mechanical damage (refs. 33 and 35) to the fiber surface during hot pressing as no compliant layer (such as $\mathrm{BN}$ ) was present. In contrast, the $\mathrm{BN} / \mathrm{SiC}$ coated fiber-reinforced $\mathrm{CMC}$ shows graceful failure. The first matrix cracking stress was $\sim 400 \mathrm{MPa}$ and ultimate strength greater than $800 \mathrm{MPa}$. This shows that reinforcement of BSAS matrix with $\mathrm{BN} / \mathrm{SiC}$ coated Hi-Nicalon fiber results in a strong and tough composite. 



(a)
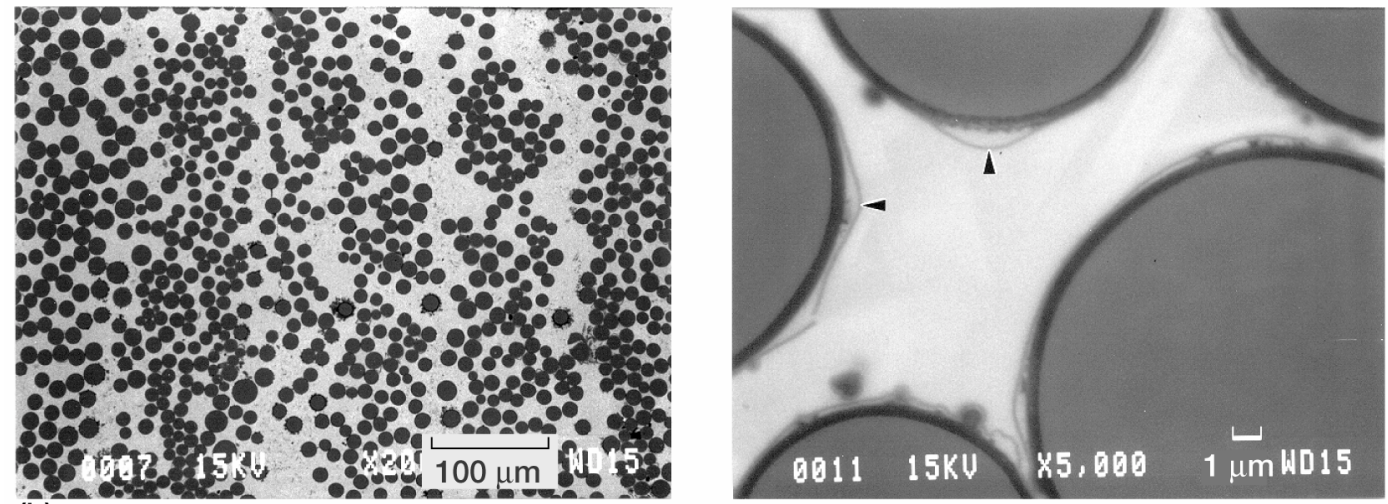

(b)

Figure 10.-SEM micrographs showing polished cross-sections of unidirectional (a) Hi-Nicalon (uncoated)/BSAS and (b) Hi-Nicalon/BN/SiC/BSAS composites.

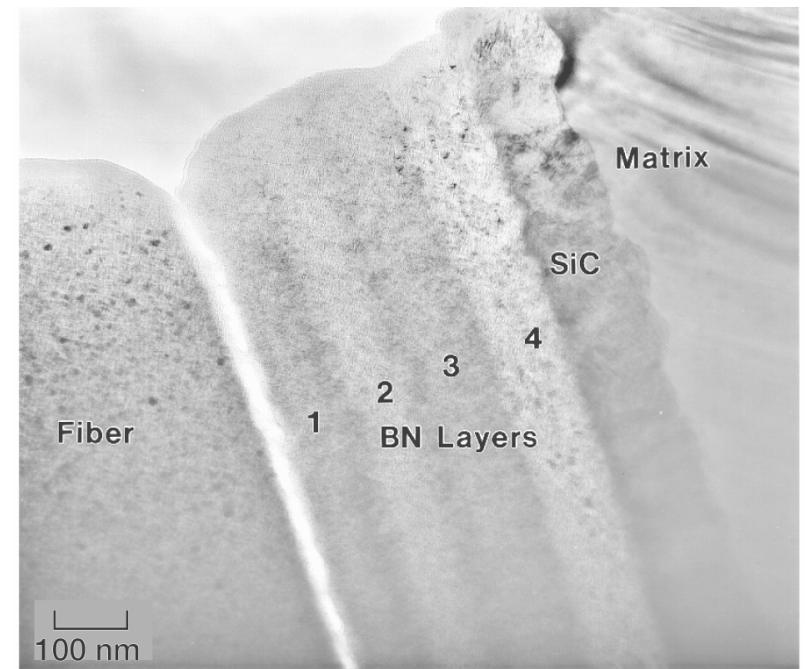

(a)



(b)

Figure 11.-TEM bright field image from cross-section of Hi-Nicalon/BN/SiC/BSAS composite showing (a) multiple BN layers and (b) coarsening of the outer three BN layers. The inner BN and the SiC interface layers are unaffected. 


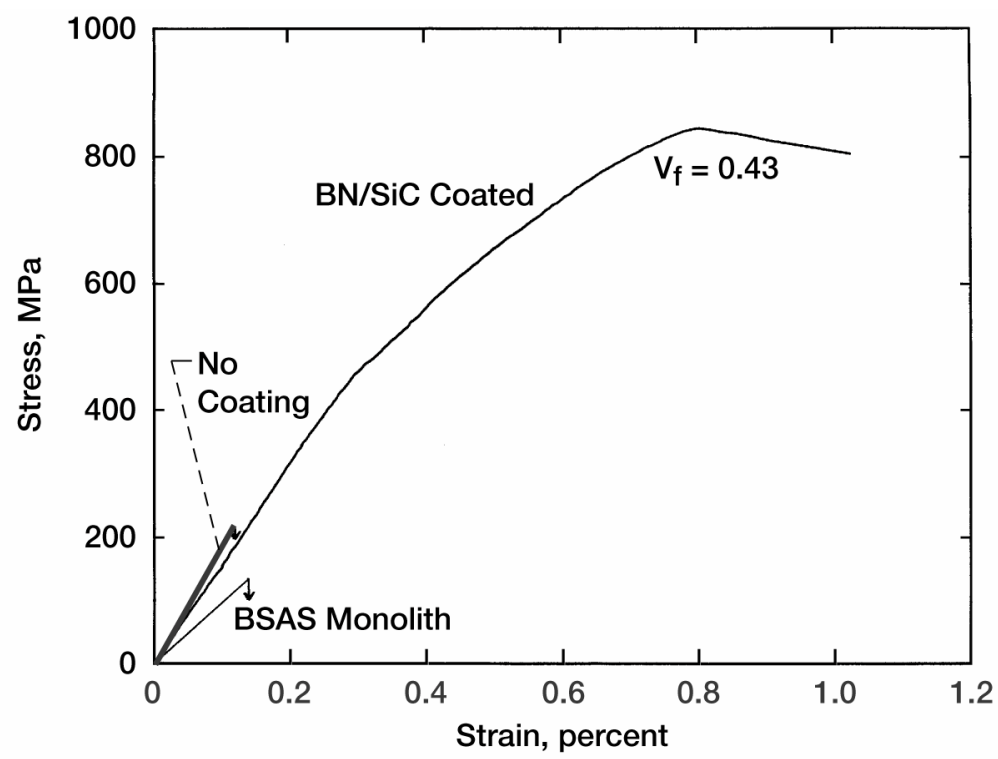

Figure 12.-Stress-strain curves for unidirectional uncoated and $\mathrm{BN} / \mathrm{SiC}$-coated Hi-Nicalon/BSAS composites recorded in 3-point flexure; also shown is the curve for hot pressed monolithic BSAS.

Table 6.-Tensile properties of unidirectional Hi-Nicalon/BN/SiC/BSAS composites at various temperatures in air, $V_{f}=0.30$

\begin{tabular}{|l|c|c|c|c|c|}
\hline $\begin{array}{c}\text { Temperature, } \\
{ }^{\circ} \mathrm{C}\end{array}$ & $\begin{array}{c}\text { Modulus, } E_{c} \\
\mathrm{GPa}\end{array}$ & $\begin{array}{c}\text { Yield stress, } \sigma_{y} \\
\mathrm{MPa}\end{array}$ & $\begin{array}{c}\text { Yield strain, } \\
\text { percent }\end{array}$ & $\begin{array}{c}\text { Ultimate strength, } \sigma_{u} \\
\mathrm{MPa}\end{array}$ & $\begin{array}{c}\text { Failure strain, } \\
\text { percent }\end{array}$ \\
\hline 25 & $154 \pm 2$ & $97 \pm 15$ & $0.064 \pm 0.09$ & $589 \pm 15$ & $0.45 \pm 0.01$ \\
\hline 800 & $132 \pm 3$ & $68 \pm 6$ & $0.052 \pm 0.06$ & $448 \pm 4$ & $0.41 \pm 0.03$ \\
\hline 1000 & $106 \pm 3$ & $70 \pm 7$ & $0.064 \pm 0.09$ & $480 \pm 25$ & 0.40 \\
\hline 1100 & $91 \pm 3$ & $92 \pm 6$ & $0.10 \pm 0.005$ & $400 \pm 2$ & $0.47 \pm 0.05$ \\
\hline 1200 & $73 \pm 5$ & $99 \pm 40$ & 0.074 & $370 \pm 12$ & -- \\
\hline
\end{tabular}

\subsection{Tensile Strength}

Tensile properties of unidirectional $\mathrm{BN} / \mathrm{SiC}$ coated Hi-Nicalon fiber reinforced celsian matrix composites (refs. 36 and 37) from room temperature to $1200{ }^{\circ} \mathrm{C}$ in air are shown in table 6 . The value of Young's modulus decreased with increase in test temperature indicating the presence of glassy phase in the matrix. The yield stress decreased from room temperature to $800^{\circ} \mathrm{C}$ followed by a slight increase to $1200^{\circ} \mathrm{C}$. Ultimate strength decreased with temperature. SEM micrographs of the fracture surfaces of the composite specimens after tensile tests showed extensive fiber pullout. Fracture surfaces of samples tested at $1000{ }^{\circ} \mathrm{C}$ or higher showed the presence of pores in the matrix which were more predominant in the $1200{ }^{\circ} \mathrm{C}$ tested specimen. This may be due to oxidation of the Hi-Nicalon fibers producing a gaseous product and also oxidation of the BN coating producing a low melting glassy phase that is partially blown out of the interior of the composite by the escaping gases.

Effect of test rate on ultimate tensile strength of $0 / 90^{\circ} \mathrm{Hi}$-Nicalon/BSAS composite at $1100{ }^{\circ} \mathrm{C}$ in air has also been investigated (ref. 32). Results in figure 7 exhibit a significant dependency of ultimate strength on test rate. The ultimate strength decreased with decreasing test rate, similar to the behavior observed in many advanced monolithic ceramics (or brittle materials including glass and glass ceramics) at ambient or elevated temperature. 


\subsection{Shear Strength}

In-plane and interlaminar shear strength of composites have been measured by the double-notch shear test method at a displacement rate of $2 \times 10^{-3} \mathrm{~mm} / \mathrm{s}$. Results for a unidirectional Hi-Nicalon/BN/SiC/BSAS composite containing 42 volume percent of fibers from room temperature to $1200{ }^{\circ} \mathrm{C}$ are shown (refs. 38 and 39) in figure 13. The interlaminar shear strength is lower than the in-plane shear strength at all temperatures. A rapid decrease in strength with temperature is probably due to softening of the residual glassy phase in the matrix.

Test rate dependence of interlaminar and in-plane shear strengths of CMC have also been investigated (refs. 40 and 41) using double notch shear (DNS) test specimens. Typical load versus time curves for two different test rates are shown in figure 14. The effects of test rate on shear strengths of a unidirectional Hi-Nicalon $^{\mathrm{TM}}$ fiber-reinforced BSAS composite at $1100{ }^{\circ} \mathrm{C}$ in air are presented in figure 15 . The composite exhibited a significant effect of test rate on shear strength, regardless of orientation which was either in interlaminar or in in-plane region. Shear-strength degraded by about 50 percent as test rate decreased from $3.3 \times 10^{-1} \mathrm{~mm} / \mathrm{s}$ to $3.3 \times 10^{-5} \mathrm{~mm} / \mathrm{s}$. The rate dependency of composite's shear strength was very similar to that of ultimate tensile strength at $1100{ }^{\circ} \mathrm{C}$ observed (ref. 32) in a similar composite (2-D Hi-Nicalon/BSAS) in which ultimate tensile strength decreased by about 60 percent when test rate changed from the highest $(5 \mathrm{MPa} / \mathrm{s})$ to the lowest $(0.005 \mathrm{MPa} / \mathrm{s})$. A phenomenological, power-law slow crack growth formulation has been proposed (refs. 40 and 41) to account for the rate dependency of shear strength of the composite.

Results of shear strength $\left(\tau_{f}\right)$ as a function of applied shear stress rate $(\dot{\tau})$ based on

$$
\log \tau_{f}=\frac{1}{n_{s}+1} \log \dot{\tau}+\log D_{s}
$$

with displacement rate being converted to shear stress rate are shown in figure 16 . Here $n_{\mathrm{s}}$ and $D_{s}$ are the slow crack growth (SCG) parameters. The values of SCG parameters were determined as $n_{s}=11.2$ and $D_{s}=19.24$ for interlaminar direction and $n_{s}=11.4$ and $D_{s}=33.27$ for in-plane direction. It is noteworthy that the value of $n_{s}$, a measure of susceptibility to SCG, was same in both directions. The value of SCG parameter $n_{s}(=11)$ in shear also compares with that of $n(=7)$ in tension for the similar 2-D Hi-Nicalon/BSAS composite tested at $1100{ }^{\circ} \mathrm{C}$ in air (ref. 32), indicating that the Hi-Nicalon/BSAS composites exhibit significant susceptibility to SCG in both shear and tension. In general, the patterns of SCG for many monolithic advanced ceramics tested at elevated temperatures are well defined in fracture surfaces in terms of its configuration and size. By contrast, the patterns of SCG for CMCs subjected to either in tension or in shear are not obvious and rather obscured by the nature of composite architecture so that it would be very difficult and/or a great challenge to derive a definite evidence of SCG from overall fracture surface examinations. Hence, the study of shear strength degradation with respect to test rate through constant stress-rate testing is a simple, quick and convenient way to check and quantify the degree of SCG in shear for CMCs at elevated temperatures. The residual glassy phase may have been a major cause of SCG in the Hi-Nicalon/BSAS composite under shear. Life prediction diagram (applied shear stress vs. time to failure) in shear for interlaminar and in-plane directions for Hi-Nicalon/BSAS composite (ref. 41) at $1100^{\circ} \mathrm{C}$ in air is shown in figure 17. 


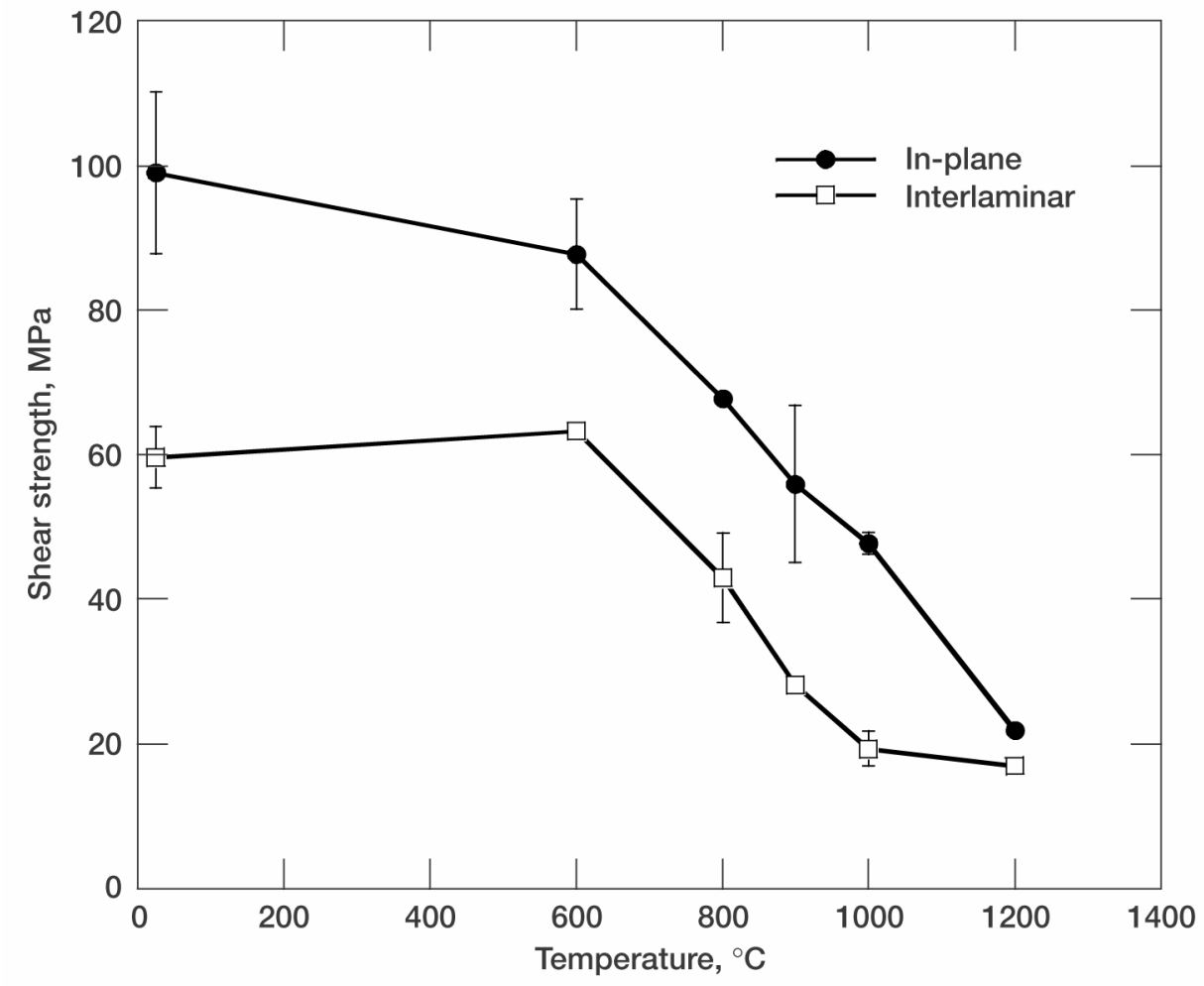

Figure 13.-Temperature dependence of interlaminar and in-plane shear strength of Hi-Nicalon/BSAS composite in air.
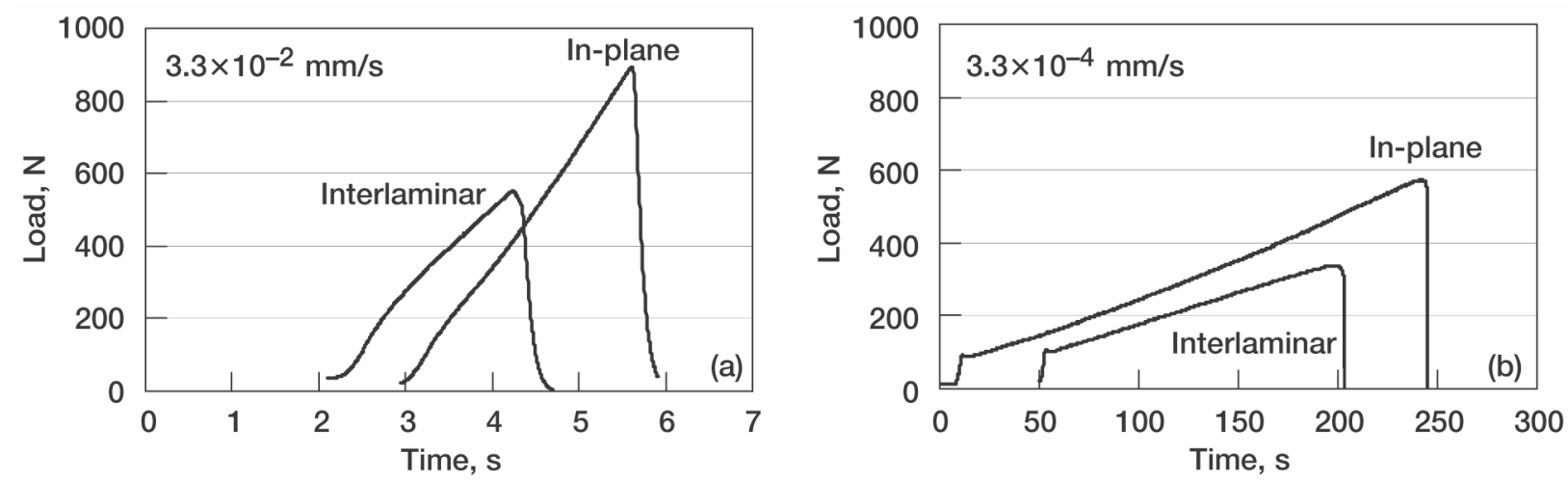

Figure 14.-Typical load-time curves for Hi-Nicalon/BSAS composite tested in interlaminar and in-plane shear at $1100{ }^{\circ} \mathrm{C}$ in air. (a) Fast test rate of $3.3 \times 10^{-2} \mathrm{~mm} / \mathrm{s}$. (b) Slow test rate of $3.3 \times 10^{-4} \mathrm{~mm} / \mathrm{s}$. 


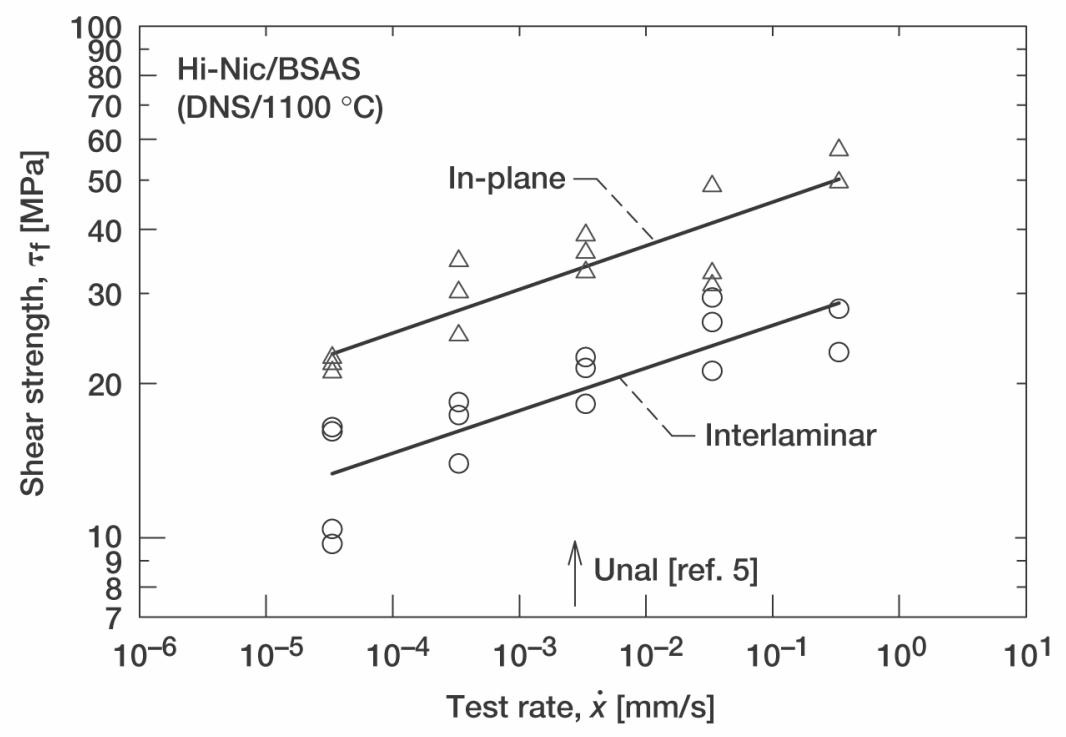

Figure 15.-Effect of test rate on interlaminar and in-plane shear strengths for $\mathrm{Hi}-\mathrm{Nicalon} / \mathrm{BSAS}$ composite tested at $1100{ }^{\circ} \mathrm{C}$ in air. The arrow in the 'test-rate' axis indicates the test rate used by Unal and Bansal [38-39].

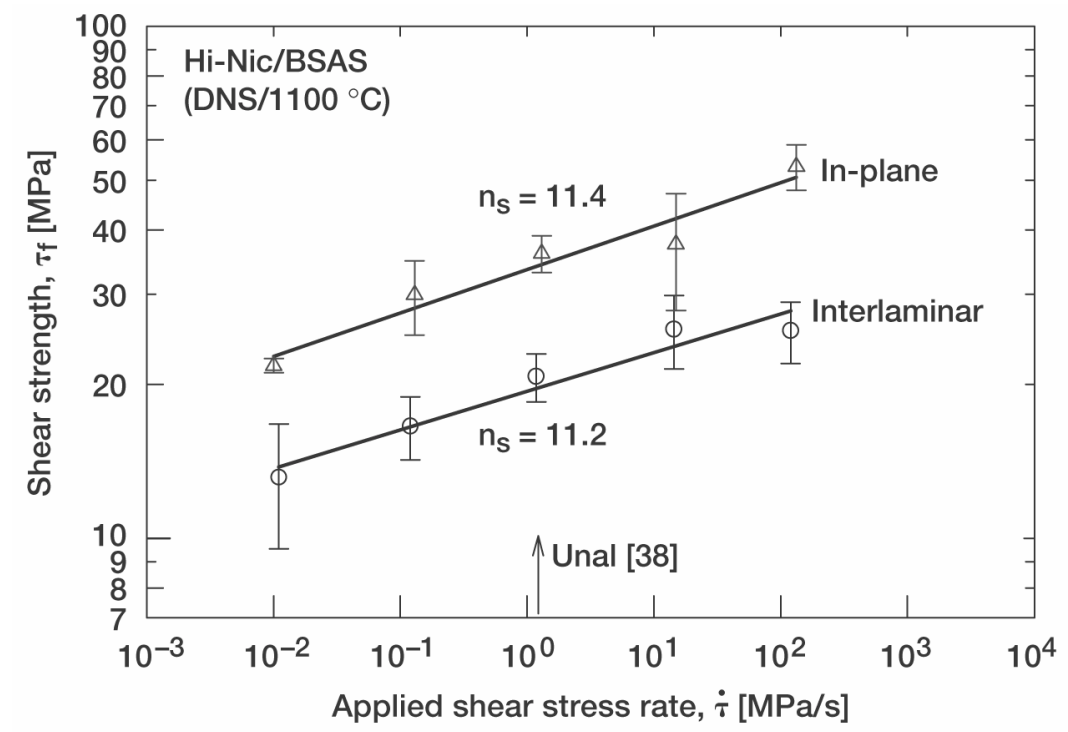

Figure 16.-Shear strength as a function of applied shear stress rate for Hi-Nicalon/BSAS composite at $1100{ }^{\circ} \mathrm{C}$ in air, reconstructed from the data in Fig. 15 based on eq. (2). The arrow in the 'stress-rate' axis indicates the stress rate used by Unal and Bansal [38-39]. 


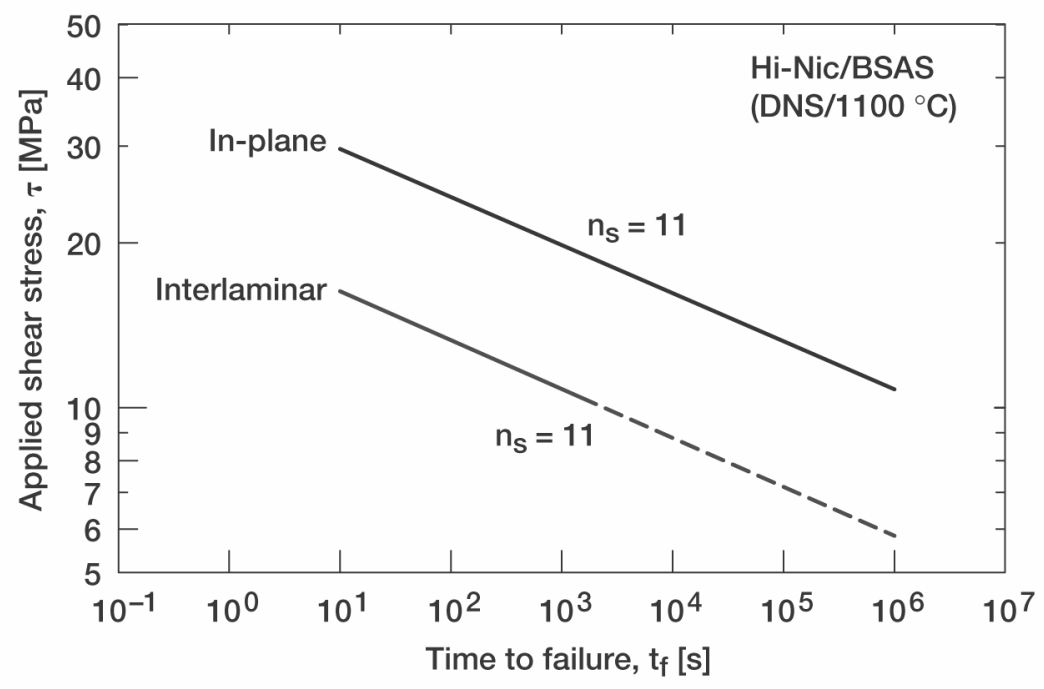

Figure 17.-Life prediction diagram in shear for Hi-Nicalon/BSAS composite at $1100{ }^{\circ} \mathrm{C}$ in air in-interlaminar and in-inplane directions under constant stress condition.

\subsection{Thermo-Oxidative Stability}

6.4.1 Effects of high-temperature annealing in air.-Thermal-oxidative stability of Hi-Nicalon/BN/ $\mathrm{SiC} / \mathrm{BSAS}$ composites has also been investigated (refs. 42 and 43). Unidirectional composites were annealed for $100 \mathrm{hr}$. in air at various temperatures. Optical photographs showing the physical appearance of the CMC bars before and after annealing at various temperatures are shown in figure 18. No changes in physical appearance were observed in samples annealed at $1000^{\circ} \mathrm{C}$ or lower. However, the specimen annealed at $1100^{\circ} \mathrm{C}$ was covered with a thin porous white layer that could be easily removed by polishing with a fine emery paper. The samples aged at $1200^{\circ} \mathrm{C}$ were deformed and developed a thick shiny white glaze on the exposed surfaces. Pores were present in the surface layer. Signs of partial melting and gas bubble formation during heat treatment were also observed. From XRD analysis, both amorphous and Celsian phases were detected in the surface layer. Since such a behavior was not observed (ref. 44) in monolithic BSAS material even after heat treatment for $20 \mathrm{hr}$. in air at $1500{ }^{\circ} \mathrm{C}$, it must be caused by the presence of Hi-Nicalon fibers and/or the $\mathrm{BN} / \mathrm{SiC}$ coating. In air, $\mathrm{BN}$ is probably oxidized to $\mathrm{B}_{2} \mathrm{O}_{3}$ which reacts with the matrix and/or silica formed from the oxidation of silicon carbide fibers, resulting in lowmelting glassy phase which migrates to the sample surface. The bubble formation may be related to the oxidation of Hi-Nicalon fibers producing amorphous silica and $\mathrm{CO}$ and $\mathrm{CO}_{2}$ gases.

The matrix layers on the surface of CMC specimens annealed at 1100 and $1200{ }^{\circ} \mathrm{C}$ appear to have cracked and delaminated as seen in the SEM micrographs (fig. 19), taken from the polished crosssections. A large difference in the coefficients of thermal expansion (CTE) of Hi-Nicalon fiber $\left(\sim 3.5 \times 10^{-6} /{ }^{\circ} \mathrm{C}\right)$ and the matrix may be responsible for the observed cracking and delamination. This would provide an easy path for the ingression of oxygen to the fiber bundles and accelerate the degradation of fibers from oxidation. No such cracking or delamination was observed in samples annealed at lower temperatures. Higher magnification SEM micrographs from the $1200{ }^{\circ} \mathrm{C}$ annealed specimens showed the presence of gas bubbles on its surface. Severe damage was also observed underneath the top debonded layer where damaged broken pieces of the fibers are also present. 

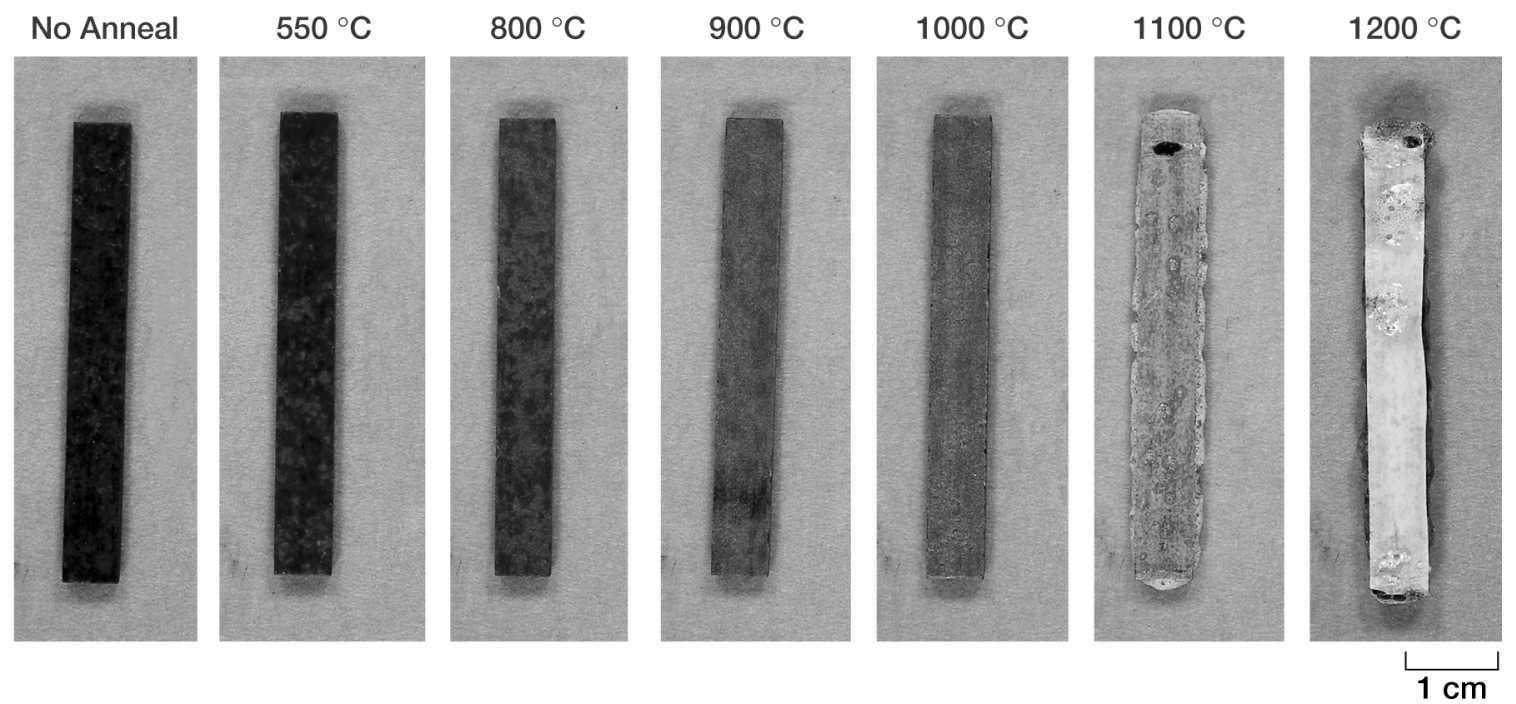

Figure 18.-Optical photographs showing surface appearance of Hi-Nicalon/BSAS composites after $100 \mathrm{~h}$ air-annealing at various temperatures.

No Anneal

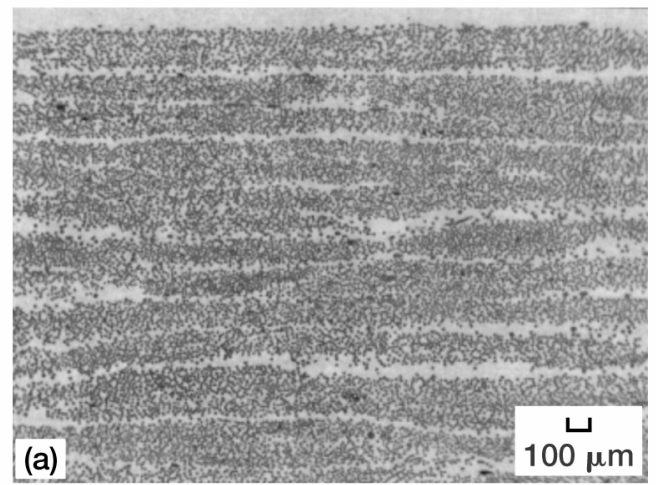

$1100^{\circ} \mathrm{C}$

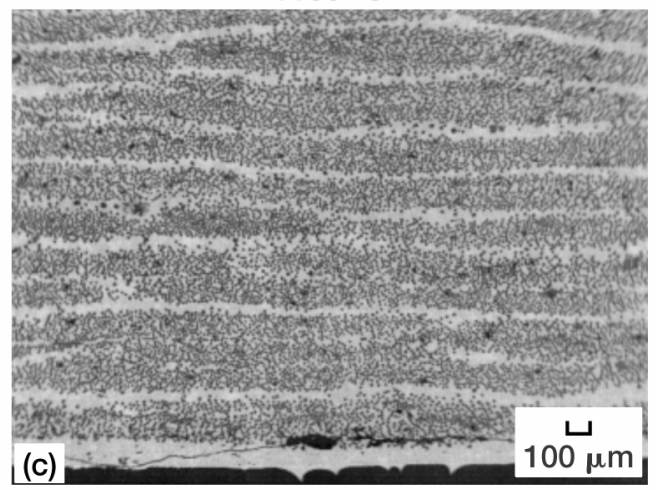

$1000^{\circ} \mathrm{C}$

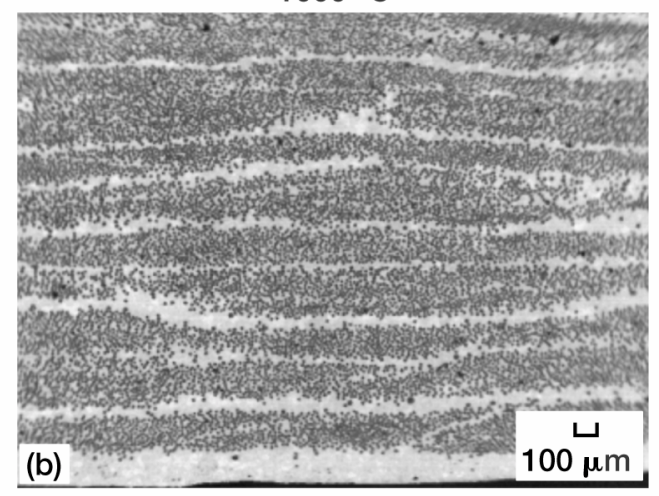

$1200{ }^{\circ} \mathrm{C}$

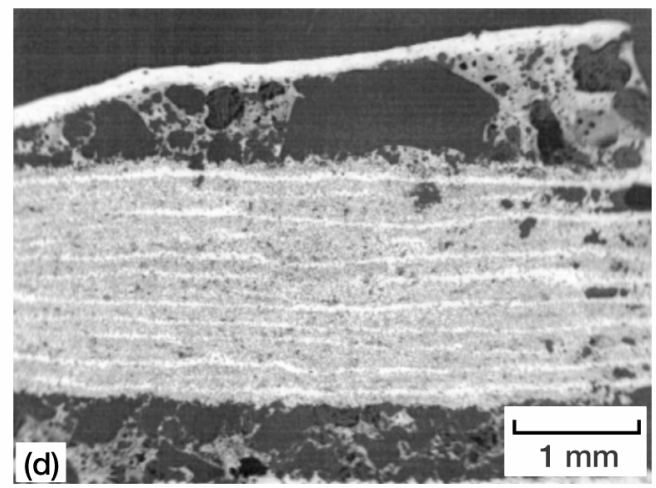

Figure 19.-SEM micrographs showing polished cross-sections of unidirectional Hi-Nicalon/ BSAS composites annealed for $100 \mathrm{~h}$ in air at various temperatures; $V_{f}=0.32$. 
Table 7. Mechanical properties* of unidirectional Hi-Nicalon/BN/SiC/BSAS

composites annealed at various temperatures for $100 \mathrm{hr}$. in air, $V_{f}=0.32$

\begin{tabular}{|l|c|c|c|c|c|c|}
\hline $\begin{array}{c}\text { Annealing } \\
\text { Temperature, } \\
{ }^{\circ} \mathrm{C}\end{array}$ & $\begin{array}{c}\text { Density, } \\
\mathrm{g} / \mathrm{cm}^{3}\end{array}$ & $\begin{array}{c}\text { Weight change } \\
\text { after annealing, } \\
\text { percent }\end{array}$ & $\begin{array}{c}E_{c}, \\
\mathrm{GPa}\end{array}$ & $\begin{array}{c}\sigma_{y}, \\
\mathrm{MPa}\end{array}$ & $\begin{array}{c}\varepsilon_{y}, \\
\text { percent }\end{array}$ & $\begin{array}{c}\sigma_{u}, \\
\mathrm{MPa}\end{array}$ \\
\hline----- & $3.09 \pm 0.03$ & -- & 137 & 122 & 0.091 & 759 \\
\hline 550 & 3.12 & -- & 145 & 155 & 0.108 & 853 \\
\hline 800 & 3.06 & -- & 150 & 138 & 0.096 & 814 \\
\hline 900 & 3.16 & -- & 151 & 171 & 0.114 & 769 \\
\hline 1000 & 3.04 & -- & 146 & 134 & 0.092 & 819 \\
\hline 1100 & 2.90 & -- & 142 & 143 & 0.102 & 736 \\
\hline 1200 & Deformed & +0.43 & -- & -- & -- & -- \\
\hline
\end{tabular}

*Measured at room temperature in 3-point flexure

Flexure strengths of the annealed CMC specimens were measured at room temperature in 3-point bending. The strain-stress curves of the CMCs annealed at various temperatures are presented in figure 20 and the results are summarized in table 7. Up to the annealing temperature of $1100{ }^{\circ} \mathrm{C}$, no net change was observed in the weights of samples. Also, values of Young's modulus $\left(E_{c}\right)$, yield stress $\left(\sigma_{y}\right)$, yield strain $\left(\varepsilon_{y}\right)$, and ultimate strength $\left(\sigma_{u}\right)$ did not change. However, the specimen annealed at $1200{ }^{\circ} \mathrm{C}$, gained 0.43 percent weight and had appreciably deformed and its strength could not be measured.

6.4.2 Degradation mechanism at $1200{ }^{\circ} \mathrm{C}$.- - Various steps involved in the degradation of $\mathrm{Hi}-\mathrm{Nicalon} / \mathrm{BN} / \mathrm{SiC} / \mathrm{BSAS} \mathrm{CMC}$ on annealing in air at $1200^{\circ} \mathrm{C}$ are shown in figure 21 . During annealing at $1200{ }^{\circ} \mathrm{C}$, the surface matrix layer delaminates from the composite ply underneath (SEM micrograph of fig. 19), probably due to the large CTE mismatch between the Hi-Nicalon fibers and the celsian matrix. This facilitates the ingression of oxygen into the composite. This causes the oxidation of $\mathrm{SiC}$ fibers, particularly those which have lost the duplex CVD coating (see fig. 10), resulting in the formation of $\mathrm{SiO}_{2}$ :

$$
\mathrm{SiC}(\mathrm{s})+\mathrm{O}_{2}(\mathrm{~g}) \rightarrow \mathrm{SiO}_{2}(\mathrm{~s})+\mathrm{CO}(\mathrm{g})+\mathrm{CO}_{2}(\mathrm{~g})
$$

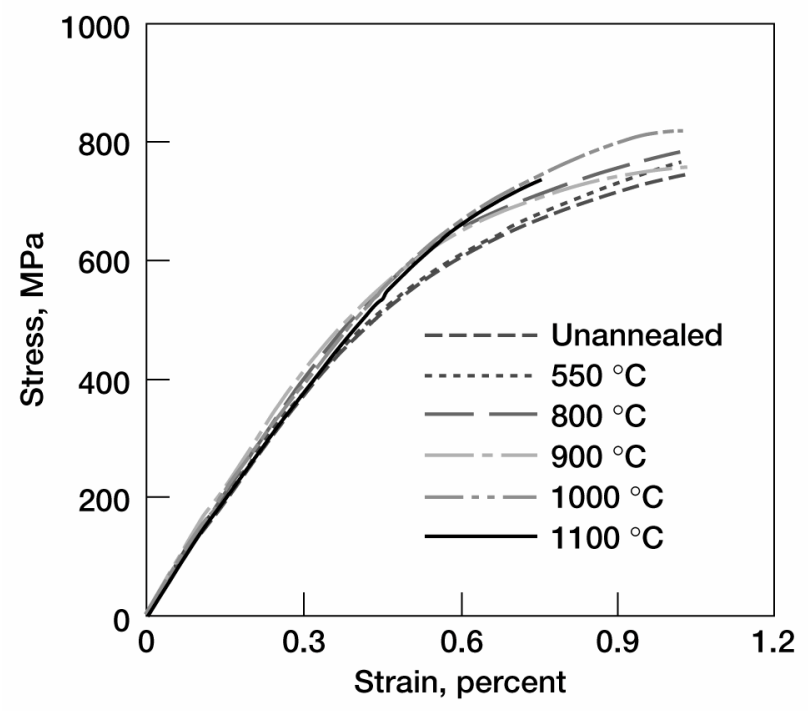

Figure 20.-Room temperature stress-strain curves recorded in 3-point flexure for unidirectional HiNicalon/BSAS composites annealed for $100 \mathrm{~h}$ in air at various temperatures; $V_{f}=0.32$.
The silica formed reacts with celsian resulting in the formation of a low melting phase. The phase diagram of $\mathrm{BaO}-\mathrm{Al}_{2} \mathrm{O}_{3}-\mathrm{SiO}_{2}$ system (fig. 22) (ref. 45) does show the presence of a ternary phase with a melting point of $1122{ }^{\circ} \mathrm{C}$. This phase is richer in $\mathrm{SiO}_{2}$ but poorer in $\mathrm{BaO}$ and $\mathrm{Al}_{2} \mathrm{O}_{3}$ than celsian. Formation of gaseous by-products $\mathrm{CO}$ and $\mathrm{CO}_{2}$ during reaction (3) results in the evolution of bubbles as observed in SEM micrograph of figure 19. On cooling, celsian crystals precipitate from the melt leaving behind a glassy matrix which is richer in $\mathrm{SiO}_{2}$ and poorer in $\mathrm{BaO}$ and $\mathrm{Al}_{2} \mathrm{O}_{3}$ than celsian. SEM micrograph taken from the surface of CMC annealed at $1200{ }^{\circ} \mathrm{C}$ showed the presence of elongated crystals in glassy matrix. From qualitative EDS analysis, these crystals were seen to be celsian and the glassy matrix was richer in $\mathrm{SiO}_{2}$ but poorer in $\mathrm{BaO}$ and $\mathrm{Al}_{2} \mathrm{O}_{3}$ than celsian. The XRD analysis showed only celsian in the asfabricated sample whereas celsian and an amorphous phase were present in the $1200{ }^{\circ} \mathrm{C}$ annealed $\mathrm{CMC}$. Formation of a low-melting glass 
phase has also been reported (ref. 3) in the study of BSAS environmental barrier coating (EBC) on Si-based ceramic substrates such as CVD $\mathrm{SiC}$ and $\mathrm{SiC}_{\mathrm{f}} / \mathrm{SiC}$ composite. On heat treatment, the plasma sprayed BSAS coating reacted with the silica layer, formed from oxidation of the Si-based ceramic substrate, resulting in low melting ternary glass phase which was found to be richer in $\mathrm{SiO}_{2}$ but poorer in $\mathrm{BaO}$ and $\mathrm{Al}_{2} \mathrm{O}_{3}$ than celsian.

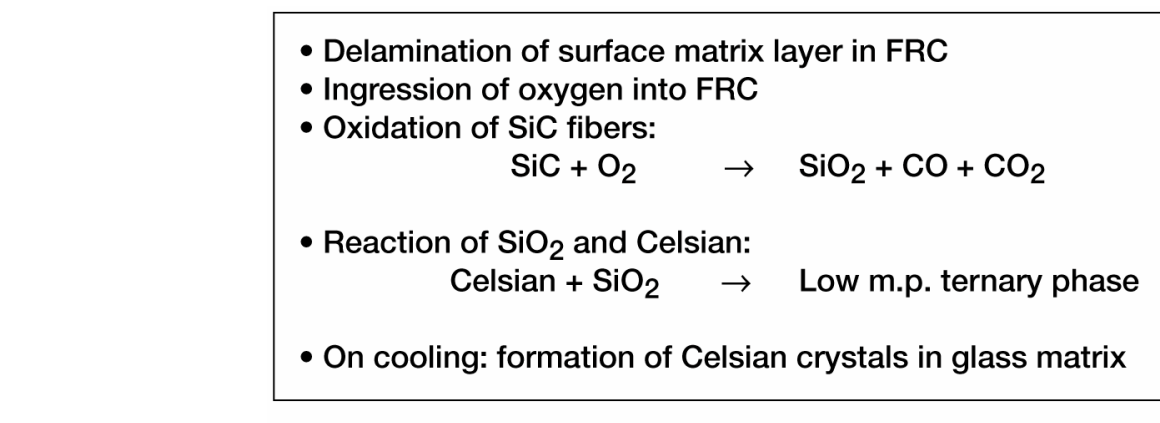

Figure 21.-Proposed degradation mechanism of Hi-Nicalon/BSAS composites at $1200^{\circ} \mathrm{C}$ in air.

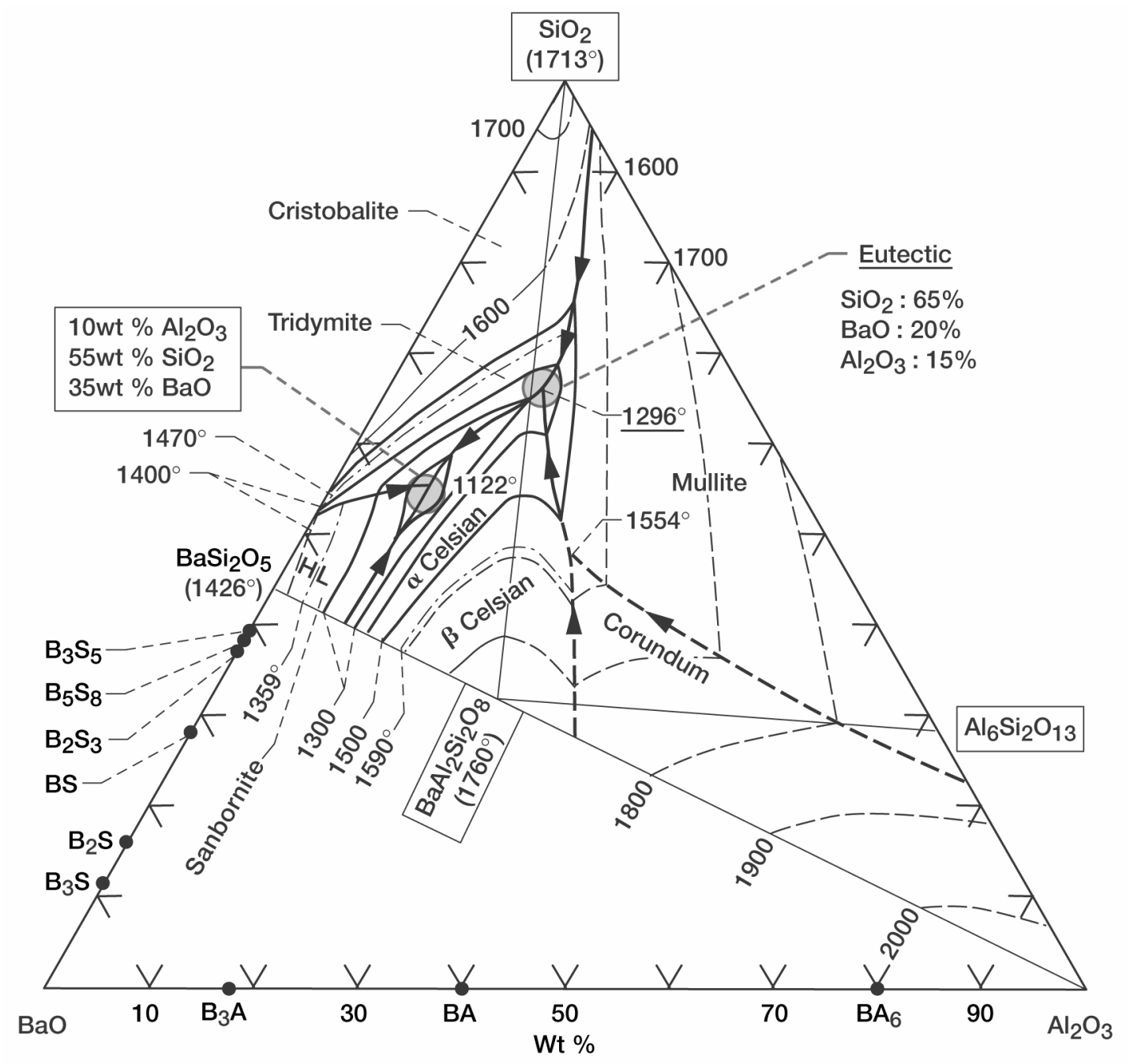

Figure 22.-Phase diagram of $\mathrm{BaO}-\mathrm{Al}_{2} \mathrm{O}_{3}-\mathrm{SiO}_{2}$ system. 


\section{Concluding Remarks}

Hi-Nicalon/Celsian composites are stable up to use temperature of $\sim 1100{ }^{\circ} \mathrm{C}$ in oxidizing environments and degrade at higher temperatures due to the instability of polymer-derived fibers. The stability of Celsian matrix composites may be extended to higher temperatures by more uniform and stable interface coating(s) and by reinforcement with more advanced silicon carbide fiber (Sylramic) for applications as hot components (combustion liner, air foil, nozzle, etc.) in turbine engines.

\section{References}

1. Prewo, K.M., Fiber Reinforced Glasses and Glass-Ceramics, in "Glasses and Glass- Ceramics," Lewis, M.H., Ed., Chapman and Hall, New York, NY, 1989; pp. 336-368.

2. Brennan, J.J., Glass and Glass-Ceramic Matrix Composites, in "Fiber Reinforced Ceramic Composites. Materials, Processing and Technology," Mazdiyasni, K.S., Ed., Noyes Publications, Park Ridge, NJ, 1990, pp. 222-259.

3. Lee, K.N., Fox, D.S., Eldridge, J.I., Zhu, D., Robinson, R.C., Bansal, N.P., and Miller, R.A., Upper Temperature Limit of Environmental Barrier Coatings Based on Mullite and BSAS, NASA/TM-2002211372, March 2002. J. Am. Ceram. Soc., 86 [8] 1299-1306 (2003).

4. Eaton, Jr., H.E., Allen, W.P., Jacobson, N.S., Bansal, N.P., Opila, E.J., Smialek, J.L., Lee, K.N., Spitsberg, I.T., Wang, H., Meschter, P.J., and Luthra, K.L., Silicon Based Substrate with Environmental/ Thermal Barrier Layer, U.S. Patent 6,387,456; May 14, 2002.

5. Bansal, N.P., Ceramic Fiber-Reinforced Glass-Ceramic Matrix Composites, U.S. Patent 5,214,004; May 25, 1993.

6. Bansal, N.P., Method of Producing a Ceramic Fiber-Reinforced Glass-Ceramic Matrix Composite, U.S. Patent 5,281,559; January 25, 1994.

7. Bansal, N.P., Method of Producing a Silicon Carbide Fiber Reinforced Strontium Aluminosilicate Glass-Ceramic Matrix Composite, U.S. Patent 5,389,321; February 14, 1995.

8. Bansal, N.P., Mechanical Behavior of Silicon Carbide Fiber-Reinforced Strontium Aluminosilicate Glass-Ceramic Composites, Mater. Sci. Eng. A, 231 [1-2] 117-127 (1997).

9. Bansal, N.P., CVD SiC (SCS-0) Fiber-Reinforced Strontium Aluminosilicate Glass-Ceramic Composites, J. Mater. Res., 12 [3] 745-753 (1997).

10. Bansal, N.P., Influence of Fiber Volume Fraction on Mechanical Behavior of CVD SiC Fiber $/ \mathrm{SrAl}_{2} \mathrm{Si}_{2} \mathrm{O}_{8}$ Glass-Ceramic Matrix Composites, SAMPE J. Advanced Mater., 28 [1] 48-58 (1996).

11. Bansal, N.P., CVD SiC Fiber-Reinforced Barium Aluminosilicate Glass-Ceramic Matrix Composites, Mater. Sci. Eng. A, 220 [1-2] 129-139 (1996).

12. Bansal, N.P., Celsian Formation in Fiber-Reinforced Barium Aluminosilicate Glass-Ceramic Matrix Composites, Mater. Sci. Eng. A, 342 [1-2] 23-27 (2003).

13. Moya Corral, J.S., and Verduch, G., The Solid Solution of Silica in Celsian, Trans. J. Br. Ceram. Soc., 77, 40-44 (1978).

14. Bahat, D., Kinetic Study on the Hexacelsian-Celsian Phase Transformation, J. Mater. Sci., 5, 805-810 (1970).

15. Yoshiki, B., and Matsumoto, K., High Temperature Modification of Barium Feldspar, J. Am. Ceram. Soc., 34 [9], 283-286 (1951).

16. Takeuchi, Y., A Detailed Investigation of the Structure of Hexagonal $\mathrm{BaAl}_{2} \mathrm{Si}_{2} \mathrm{O}_{8}$ With Reference to its a-beta Inversion, Min. J. Japan, 2[5], 311-332 (1958).

17. Newnham, R.E., and Megaw, H.D., The Crystal Structure of Celsian (Barium Feldspar), Acta Cryst., 13, 303-312 (1960).

18. Gay, P., A Note on Celsian, Acta Cryst., 9, 474 (1956). 
19. Guillem, M.C., and Guillem, C., Kinetics and Mechanism of Formation of Celsian from Barium Carbonate and Kaolin, Trans. J. Br. Ceram. Soc., 83, 150-154 (1984).

20. Bansal, N.P., Solid State Synthesis and Properties of Monoclinic Celsian, J. Mater. Sci., 33 [19] $4711-$ 4715 (1998).

21. Buzniak, J.J., Lagerlof, K.P.D., and Bansal, N.P., Hot Pressing and High Temperature Mechanical Properties of $\mathrm{BaAl}_{2} \mathrm{Si}_{2} \mathrm{O}_{8}$ (BAS) and $\mathrm{SrAl}_{2} \mathrm{Si}_{2} \mathrm{O}_{8}$ (SAS), in Advances in Ceramic Matrix Composites (Bansal N.P., Ed.), Am. Ceram. Soc., Westerville, OH; Ceram. Trans., 38, 789-801 (1993).

22. Zhu, D., Bansal, N.P., Lee, K.N., and Miller, R.A., Thermal Conductivity of Ceramic Thermal Barrier and Environmental Barrier Coating Materials, NASA/TM-2001-211122, Sept. 2001.

23. Bansal, N.P., and Hyatt, M.J., Crystallization Kinetics of Barium Aluminosilicate Glasses, J. Mater. Res., 41257 (1989).

24. Hyatt, M.J., and Bansal, N.P., Crystal Growth Kinetics in $\mathrm{BaOAl}_{2} \mathrm{O}_{3} 2 \mathrm{SiO}_{2}$ and $\mathrm{SrOAl}_{2} \mathrm{O}_{3} 2 \mathrm{SiO}_{2} \mathrm{Glasses}$ J. Mater. Sci., 31[1] 172-184 (1996).

25. Bansal, N.P., and Drummond III, C.H., Kinetics of Hexacelsian to Monoclinic Celsian Phase Transformation in $\mathrm{SrAl}_{2} \mathrm{Si}_{2} \mathrm{O}_{8}$, J. Am. Ceram. Soc., 761321 (1993).

26. Bansal, N.P., and Setlock, J.A., Fabrication of Fiber-Reinforced Celsian Matrix Composites, Comp. Part A: Applied Science and Manufacturing, 32[8] 1021-1029 (2001).

27. Bansal, N.P., Strong and Tough Hi-Nicalon Fiber-Reinforced Celsian Matrix Composites, J. Am. Ceram. Soc., 80 [9] 2407-2409 (1997).

28. Gouadec, G., Colomban, P., and Bansal, N.P., Raman Study of Hi-Nicalon Fiber-Reinforced Celsian Composites. Part 1: Distribution and Nanostructure of Different Phases, J. Am. Ceram. Soc., 84[5] 11291135 (2001).

29. Bansal, N.P., McCluskey, P.H., Linsey, G.D., Murphy, D., and Levan, G., Processing and Properties of Nicalon Reinforced Barium Aluminosilicate (BAS) Glass-Ceramic Matrix Composites, in Ceramic Matrix Composites for Rocket Nozzle, Leading Edge, and Turbine Applications, Opeka, M.M., Ed., DoD Ceramics Information Analysis Center, West Lafayette, IN; pp. 335-358 (1995).

30. Bansal, N.P., McCluskey, P.H., Linsey, G.D., Murphy, D., and Levan, G., Nicalon Fiber-Reinforced Celsian Glass-Ceramic Composites, in "HITEMP Review 1995 - Advanced High Temperature Engine Materials Technology Program. Volume III: Turbine Materials ---CMC's, Fiber and Interface Issues," NASA CP-10178, pp. 41-1 to 41-14 (1995).

31. Linsey, G.D., McCluskey, P., Murphy, D., and Levan, G., Processing and Properties of Barium Aluminosilicate Glass-Ceramic Matrix Composites, NASA CR-198369, August 1995.

32. Choi, S.R., Bansal, N.P., and Gyekenyesi, J.P., Ultimate Tensile Strength as a Function of Test Rate for Various Ceramic Matrix Composites at Elevated Temperatures, NASA/TM-2002-211579, June 2002.

33. Bansal, N.P., and Eldridge, J.I., Hi-Nicalon Fiber-Reinforced Celsian Matrix Composites: Influence of Interface Modification, J. Mater. Res., 13 [6] 1530-1537 (1998).

34. Ünal, Ö., and Bansal, N.P., Temperature Dependency of Strength of a Unidirectional SiC FiberReinforced (Ba,Sr) $\mathrm{Al}_{2} \mathrm{Si}_{2} \mathrm{O}_{8}$ Celsian Composite, in Advances in Ceramic Matrix Composites IV (Singh, J.P., and Bansal, N.P., Eds.), Am. Ceram. Soc., Westerville, OH; Ceram. Trans., 96, 135-147 (1999).

35. Bansal, N.P., and Eldridge, J.I., Effects of Fiber/Matrix Interface and its Composition on Mechanical Properties of Hi-Nicalon/Celsian Composites, NASA/TM-1999-209057, March 1999; Proc. ICCM-12 Conference, Paper No. 147, Paris, France, July 1999; ISBN 2-9514526-2-4.

36. Gyekenyesi, J.Z., and Bansal, N.P., High Temperature Mechanical Properties of Hi-Nicalon FiberReinforced Celsian Composites, in Advances in Ceramic Matrix Composites V (Bansal, N.P., Singh, J.P., and Ustundag, E., Eds.), Am. Ceram. Soc., Westerville, OH; Ceram. Trans., 103, 291-306 (2000).

37. Gyekenyesi, J.Z., and Bansal, N.P., High Temperature Tensile Properties of Unidirectional Hi-Nicalon/ Celsian Composites in Air, NASA/TM-2000-210214, July 2000.

38. Ünal, Ö., and Bansal, N.P., Interlaminar Shear Strength of a Unidirectional Fiber-Reinforced Celsian Composite by Short-Beam and Double-Notched Shear Tests, Ceram. Eng. Sci. Proc., 22 [3] 585-595 (2001). 
39. Ünal, Ö., and Bansal, N.P., In-Plane and Interlaminar Shear Strength of Silicon Carbide Fiber-Reinforced Celsian Composite, Ceram. Int., 28 [5] 527-540 (2002).

40. Choi, S.R., Bansal, N.P., and Gyekenyesi, J.P., Rate Dependency of Shear Strength in $\mathrm{SiC}_{\mathrm{f}} / \mathrm{BSAS}$ Composite at Elevated Temperature, Ceram. Eng. Sci. Proc., 24 (2003).

41. Choi, S.R., Bansal, N.P., and Gyekenyesi, J.P., Dependency of Shear Strength on Test Rate in SiC/BSAS Ceramic matrix Composite at Elevated Temperature, NASA/TM-2003-212182, April 2003.

42. Bansal, N.P., Mechanical Properties of SiC Fiber-Reinforced Celsian Composites After HighTemperature Exposures in Air, in Proc. 8th International Conference on Composites Engineering (ICCE-8), Hui, D., Ed., Tenerife, Spain, August 5-11 (2001); p. 59.

43. Bansal, N.P., Effects of Thermal Ageing in air on Microstructure and Mechanical Properties of Hi-Nicalon Fiber-Reinforced Celsian Composites, unpublished work.

44. Bansal, N.P., Hyatt, M.J., and Drummond III, C.H., Crystallization and Properties of Sr-Ba Aluminosilicate Glass-Ceramic Matrices, Ceram. Eng. Sci. Proc., 12 [7-8] 1222-1234 (1991).

45. Levin, E.M., and McMurdie, H.F., Phase Diagram for Ceramists, Vol. III, Fig. 4544, p. 220 (1975); The Am. Ceram. Soc., Westerville, $\mathrm{OH}$. 



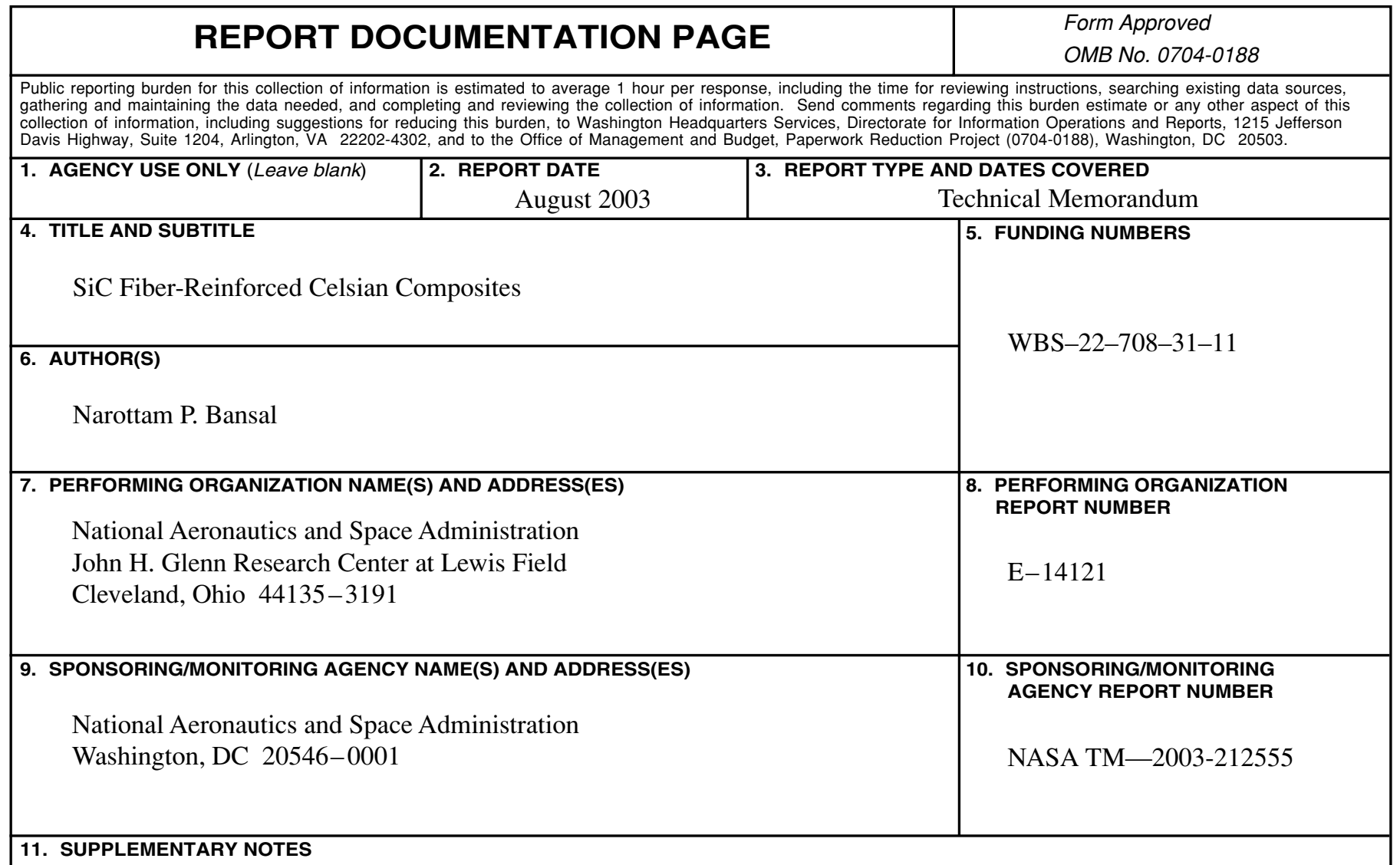

Responsible person, Narottam P. Bansal, organization code 5130, 216-433-3855.

12a. DISTRIBUTION/AVAILABILITY STATEMENT

12b. DISTRIBUTION CODE

Unclassified - Unlimited

Subject Categories: 07 and 27

Distribution: Nonstandard

Available electronically at http://gltrs.grc.nasa.gov

This publication is available from the NASA Center for AeroSpace Information, 301-621-0390.

13. ABSTRACT (Maximum 200 words)

Celsian is a promising matrix material for fiber-reinforced composites for high temperature structural applications. Processing and fabrication of small diameter multifilament silicon carbide tow reinforced celsian matrix composites are described. Mechanical and microstructural properties of these composites at ambient and elevated temperatures are presented. Effects of high-temperature exposures in air on the mechanical behavior of these composites are also given. The composites show mechanical integrity up to $\sim 1100{ }^{\circ} \mathrm{C}$ but degrade at higher temperatures in oxidizing atmospheres. A model has been proposed for the degradation of these composites in oxidizing atmospheres at high temperatures.

\begin{tabular}{|c|c|c|c|}
\hline \multicolumn{3}{|l|}{ 14. SUBJECT TERMS } & 15. NUMBER OF PAGES \\
\hline \multicolumn{3}{|c|}{$\begin{array}{l}\text { Celsian; Barium aluminosilicate; Ceramic; Composites; Fibers; Mechanical properties; } \\
\text { Silicon carbide }\end{array}$} & \\
\hline Unclassified & Unclassified & Unclassified & \\
\hline \multicolumn{3}{|l|}{ NSN 7540-01-280-5500 } & $\begin{array}{l}\text { ndard Form } 298 \text { (Rev. 2-89) } \\
\text { scribed by ANSI Std. Z39-18 } \\
-102\end{array}$ \\
\hline
\end{tabular}

